\title{
The Status of Arsenic Pollution in the Greek and Cyprus Environment: An Overview
}

\author{
Spyros K. Golfinopoulos ${ }^{1, *(\mathbb{D})}$, Soterios P. Varnavas ${ }^{2}$ and Dimitrios E. Alexakis $^{3} \mathbb{D}$ \\ 1 Department of Financial \& Management Engineering, School of Engineering, University of the Aegean, \\ Kountourioti 41, GR-82132 Chios, Greece \\ 2 Department of Geology, University of Patras, GR-26504 Patras, Greece; S.P.Varnavas@upatras.gr \\ 3 Department of Civil Engineering, Laboratory of Geoenvironmental Science and Environmental Quality \\ Assurance, University of West Attica, 250 Thivon \& P. Ralli Str, GR-12244 Athens, Greece; \\ d.alexakis@uniwa.gr \\ * Correspondence: s.golfinopoulos@fme.aegean.gr; Tel.: +30-22510-35459
}

Citation: Golfinopoulos, S.K.; Varnavas, S.P.; Alexakis, D.E. The Status of Arsenic Pollution in the Greek and Cyprus Environment: An Overview. Water 2021, 13, 224. https://doi.org/10.3390/w13020224

Received: 14 December 2020

Accepted: 13 January 2021

Published: 18 January 2021

Publisher's Note: MDPI stays neutral with regard to jurisdictional claims in published maps and institutional affiliations.

Copyright: (c) 2021 by the authors. Licensee MDPI, Basel, Switzerland. This article is an open access article distributed under the terms and conditions of the Creative Commons Attribution (CC BY) license (https:// creativecommons.org/licenses/by/ $4.0 /)$.

\begin{abstract}
This study presents an overview about the arsenic (As) contamination and its sources in two European countries. Arsenic is a highly toxic element in its inorganic form and it is carcinogenic to human seven in low concentrations. The occurrence of As in surface water, stream and marine waters, groundwater, bottled water, sediment, soil, mines, and seafood, its environmental origin, and its impacts on human health are discussed. The classes of Geoaccumulation Index for As in Greece ranges from practically uncontaminated to extremely contaminated, and in Cyprus varies between practically uncontaminated and heavily contaminated. In many cases, the As contamination reaches very high concentrations and the impacts may be crucial for the human health and ecosystems. Physicochemical properties, regional climate and geological setting are controlling the occurrence and transport of As. In Greece and Cyprus, the geology, lithology, and ore-deposits are the most important factors for the variation of As contents in water, soil, and sediment. The dominant As species are also determined by the location and the redox conditions. The findings of this paper may be useful for scientists and stakeholders monitoring the studied areas and applying measures for protection of the human and terrestrial ecological receptors (plants, avian, mammals).
\end{abstract}

Keywords: Arsenic; health effects; accumulation; transportation; sources; removal; Greece; Cyprus

\section{Introduction}

The accumulation of arsenic (As) in the living organisms is one of the most crucial topics in environmental science. Many research studies have been carried out in the recent years about As impacts on the environment and human health. Arsenic is a natural component and it is mainly detected in the groundwater, biota, soil, food, and air. Albertus Magnus isolated As in $1250 \mathrm{AD}$, its atomic number is 33 and the relative mass 74.92. It is often mentioned as metalloid because its physical and chemical properties share the same characteristics to metals and non-metals. The As belongs to the most common elements and is ranked 20th in abundance in the crust of the earth, 14th in seawater and 12th in the human body [1,2].

Arsenic can be transported via air all over the atmosphere and potentially affect the human health of the exposed population [3]. Arsenic levels in water collected from areas of sulfide mineralization and mining activities range from 1-10 $\mu \mathrm{g} \mathrm{L}^{-1}$ and rising up to $100-5000 \mu \mathrm{g} \mathrm{L}^{-1}$ [2]. The As is a famous poison by ancient years and today is used for the vaccination of sheep, as rat poison, wood preservative, in herbicides and other pesticides. The most massive mass poisoning is recorded at Bangladesh in 1996, where more than half of the population was endangered [4].

Major sources of As are related to weathering of sulphide ore deposits by the rainwater $[5,6]$. In the Eastern Mediterranean Coast the Cyprus mines associated with the Troodos 
ophiolite complex [5-8] and the Lavrion mines (Sounion Peninsula, Greece) were known since the ancient times. Their occurrence would suggest that considerable amounts of As could be released every year into the marine environment [6]. Additionally, the mixed sulphide mineralization in Hermioni Peninsula (Greece) and the associated past mining activity release, among other elements, As which finally contaminates the adjacent marine environment [9-12].

This paper provides an overview of the occurrence of As in various media in Greece and Cyprus during the last decades. There is almost no information available from the published literature discussing metal contamination in Cilician basin (NE Mediterranean) sediments [13].

The main objectives of this study are: (i) to investigate the As distribution and concentration in order to evaluate the contamination level; (ii) to assess As contents in water, soil and sediment in comparison with values given by the literature; and (iii) to present efficient methods for the removal of As from the water.

\section{Methodology}

A total of 104 indexed scientific articles, technical reports, book chapters, and conference proceedings in water, soils and sediments of Greece and Cyprus were assembled from Science Direct, Web of Science, Google Scholar, PubMed, and ResearchGate. The obtained As mean values in soil and sediments of Greece and Cyprus were used for the calculation of the Geoaccumulation Index ( $\left.\mathrm{I}_{\text {geo }}\right)$. According to Muller [14] the $\mathrm{I}_{\text {geo }}$ provides classification of sediments into seven different contamination classes, ranging from practically uncontaminated to extremely contaminated as follows: $\mathrm{I}_{\text {geo }} \leq 0$ practically uncontaminated; $0<$ Igeo $_{\text {ge }}<1$ uncontaminated to moderately contaminated; $1<$ Igeo $_{\text {ge }}<2$ moderately contaminated; $2<\mathrm{I}_{\text {geo }}<3$ moderately to heavily contaminated; $3<$ Igeo $_{\text {ge }}<4$ heavily contaminated; $4<\mathrm{I}_{\text {geo }}<5$ heavily to extremely contaminated; $5<\mathrm{I}_{\text {geo }}$ extremely contaminated. The $I_{\text {geo }}$ for As is calculated as follows in Equation (1) [14]:

$$
\mathrm{I}_{\text {geo }}=\log _{2}\left[\frac{\mathrm{C}_{\mathrm{As}}}{1.5 \times \mathrm{B}_{\mathrm{As}}}\right]
$$

where $C_{A s}$ is the recorded As content in soil, sediment or rock in Greece and Cyprus; $B_{A s}$ is the concentration of As in "average shale" [15]; and 1.5 is the background matrix correction factor.

The statistical and spatial analysis were performed by applying the software platform IBM $^{\circledR}$ SPSS 26.0 for Windows (International Business Machines Corporation; Statistical Product and Service Solutions; Armonk, NY, USA) and the geographic information system ArcView 10.4 GIS (ESRI ${ }^{\circledR}$ ) (Environmental Systems Research Institute; Redlands, CA, USA), respectively. The sampling site locations and the $\mathrm{I}_{\text {geo }}$ values for As were incorporated as separate layers in the GIS database. An additional layer of spatial information, including the satellite image of Greece and Cyprus obtained from Google Earth ${ }^{\circledR}$, was inserted as a basemap in the spatial database.

\section{Health Effects}

Arsenic is highly toxic in its inorganic form and has been recognized as carcinogenic, even at low levels of concentrations [2]. Symptoms of As toxicity in human include leucomelanosis, keratosis, gangrene, skin cancer, melanosis, cancer of lungs, bladder, skin, kidney, nasal passages, prostate and liver [2]. In many cases, chronic As exposure is expected for an extended period to diagnose symptoms such as pigmentation of the skin, inability to walk and deliberating pain [16]. Arsenic is classified as Group 1 carcinogenic substance to humans, as the chronic consumption of this element can lead to carcinogenesis (skin, lung, bladder) [17]. It can also cause cardiovascular and peripheral vascular disease and diabetes [18]. According to new scientific data correlated to the adverse health effects

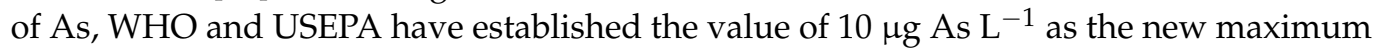
contaminant level (MCL) for As in drinking water; while the initial MCL was $50 \mu \mathrm{g}$ As 
$\mathrm{L}^{-1}$. The standard of $10 \mu \mathrm{g}$ As $\mathrm{L}^{-1}$ was also adopted by EC since 1998; while in Greek legislation was adopted on 2001 [19].

The role of Fe and $S$ in the As uptake and release from the solution and the interaction among adsorption and precipitation processes, changes in oxidation and mineral stability conditions, and the rates of these processes as mediated by the microbial activities in surface and underground environments is critical as many studies have revealed [20,21].

Historically, both $\mathrm{Pb}$ and As are used in various uses and applications. Cases of murder or suicide have been connected with the use of $\mathrm{Pb}$ and $\mathrm{As}$, as well as for illness therapies. In China since $222 \mathrm{BC}$, pharmaceutical products were made from realgar (AsS). Chronic exposure to As has been shown to have adverse effects on human health by causing, bladder cancer, liver, skin and kidneys, lungs and prostate gland, as well as coronal heart diseases and the so-called Blackfoot disease. During the antiquity, Greeks, Egyptians, Chinese and Indians mined minerals containing As. Both in the sea and stream water, the As dissolved comparatively well, ranging from $20-90 \%$ and from $60-80 \%$, respectively [22].

The As toxicity, bioavailability and the environmental fate are controlled mainly by the chemical As forms [23]. The speciation of As determines its toxicity [3]. Arsenate $(\mathrm{As}(\mathrm{V}))$ and arsenite $(\mathrm{As}(\mathrm{III}))$ are the two primary oxidation forms of As in aquatic systems. These two states generally usually co-exist but under oxidizing conditions $\mathrm{As}(\mathrm{V})$ is the most dominant, while under reducing conditions the As(III) prevails. The factors that determine this distribution include $\mathrm{pH}$, temperature, Eh, salinity, metal concentrations, distribution, and composition of the habitat $[1,24,25]$. It is well known that the As(III) species are more toxic than those of $\mathrm{As}(\mathrm{V})$ which are the most common in groundwater in the case of oxidizing conditions in contrast with reducing environments where the species of $\mathrm{As}(\mathrm{V})$ are the most common [26].

Arsenic is listed after $\mathrm{Hg}, \mathrm{Pb}$, and $\mathrm{Cd}$ as the fourth more toxic metal in European Union (EU), while in USEPA is including among two hundred hazardous substances targeted by the 1990 Clean Air Act in terms of risk as one of the more carcinogenic substances [27].

It is estimated that more than 150 million people worldwide are exposed to As through various pathways, including water consumption that contains high As levels and vegetables grown in As-contaminated soil [28]. It is estimated that globally, 100 million inhabitants are exposed to As levels above $50 \mu \mathrm{g} \mathrm{L}{ }^{-1}$ via drinking water [29]. A number of factors such as age, genetic characteristics, type of exposure (acute or chronic) and co-morbidity, duration, and magnitude of exposure, As origin and daily dietary habits determine the importance of effects on human health which is different for every organism. The As like other metals, as $\mathrm{Cd}, \mathrm{Zn}, \mathrm{Cu}$, in contrast to organic chemicals is environmentally persistent and easily is spread from soil to water, from water to the soil, and then to plants [28].

Human is exposed to As through various pathways, including drinking water, food, cigarettes, certain residential areas, cosmetics, and working environment. In the general population, the primary source of entry into the human organism is the mouth followed by inhalation and skin contact. These two sources are significant entries for the workers. Another significant pathway for the youngest is the ingestion of low levels in dust or soil through regular hand-to-mouth activities. After the absorption from the organism, the As compounds, through the liver metabolic pathway, are converted into many different types of inorganic and organic species, as $\mathrm{As}(\mathrm{III}), \mathrm{As}(\mathrm{V})$, dimethylarsinate (DMA), and monomethylarsonate (MMA). Smoking is possibly associated with reduced ability to methylate the absorbed As. It has been observed in smokers that the total urinary As and MMA concentrations are higher compared to non-smokers. One possible explanation is the fact that some chemical compounds in cigarettes compete for different enzymes or co-factors participated in the procedure of As methylation. Another source of As exposure for an extended period of time is the consumption of food in the case that food is grown in areas that have been contaminated by As or in the case where As contaminated water is used to irrigate crops [30]. Arsenic can affect almost all cellular processes and organ functions in the human body. It causes cancer in lung, bladder, skin, kidney, prostate and liver. Notably, the exposure via drinking water to low or moderate levels ranged from 
10 to $300 \mu \mathrm{g} \mathrm{L}^{-1}$ can cause skin lesions, neurological complications, diabetes, circulatory disorders, respiratory complications, hepatic, and renal dysfunction. Chronic illnesses often lead even to death [29].

\section{Accumulation}

Arsenic accumulates in organisms while the element quantity in a plant is correlated with the exposed amount [2]. The As availability in soil, the $\mathrm{pH}$ of the soil, the organic material, the redox potential and the mineral composition determine the degree of uptake, and the bio-accumulation [1]. Figure 1 presents the As cycle in the environment and its accumulation in humans, plants, animals and seafood.

\section{Transportation}

The fate and transport of As in the environment as well as its biogeochemical interactions, health effects and remediation have been subjects of investigation of many researchers [31-35].

Although the As and its compounds are mobile and not destroyed, they can interact with oxygen or other molecules. Also, the As compounds can interact with bacteria living in soil or sediment by changing the form of As, by attaching to different particles or separating from these particles. Admixed in the air, into microscopic particles, can be left for long periods and transferred away from the emission source [30]. According to Handley et al. [36], prokaryotes reduce or oxidize As and other trace elements including $\mathrm{Mn}, \mathrm{Cu}$, $\mathrm{U}, \mathrm{Cd}, \mathrm{Ag}$, and $\mathrm{Au}$, conserve energy for growth, maintenance, or for toxicity resistance of cells. At the region of Nea Kameni (Santorini Island, Greece) the subsequent reduction of $\mathrm{Mn}(\mathrm{IV}), \mathrm{Fe}(\mathrm{III})$, and sulfate to FeS with depth in the transition zone of shallow marine hydrothermal sediment was observed. In the same zone, bacteria reduce complexed $\mathrm{As}(\mathrm{V})$ related to sediments and minerals contributing to the As(III) presence. Bacteria cultivated from the above sediment convert a variety of marine and hydrothermal inorganic electron donors and acceptors, especially Fe(II), Fe(III), As(V), and As(III) [36]. Arsenic can also be transported from air to soil through the dust and atmospheric deposition. It is transported in surface and groundwater through precipitation. It may be dissolved in water causing contamination of both surface and groundwater. It is also transported over long distances, through the transfer of dust, attached to the suspended particles in the air. The As is transported to humans by animals and plants that absorb it (Figure 1). Concerning the plants, the mobility, the As speciation in pore water and the time that As is dissolved to plant roots determines and controls its uptake by them [37]. Mobilization of As largely depends on the $\mathrm{pH}$ values. Arsenic is recorded in groundwater $\mathrm{pH}$ 6.5-8.5) under both reducing and oxidizing conditions [38].

At acidic condition ( $\mathrm{pH}$ value higher than 3), the dominant ionic form of As is the $\mathrm{As}(\mathrm{V})$; while As(III) is dominant at alkaline condition ( $\mathrm{pH}$ value lower than 9). According to many researchers [38-42], few groundwater samples have been found to present only one form of $\mathrm{As}(\mathrm{V})$, others only $\mathrm{As}(\mathrm{III})$; while in some groundwater samples both As forms have been recorded in the same water body.

The determination of the As levels in 14 species of fishes and seafood was conducted in a survey that took place in six cities (Barcelona, Tarragona, Lleida, Hospitalet de Llobregat, Terrassa, and Girona) of Catalonia in Spain, during March and April 2005 [43]. The results shown highest mean concentration for red mullet (Mullus barbatus) $\left(16.6 \mathrm{mg} \mathrm{Kg}^{-1}\right.$ of fresh weight), followed by shrimp and sole (6.3 and $6.1 \mathrm{mg} \mathrm{Kg}^{-1}$, respectively) and lower As levels for tuna and salmon.

Similar results were found in a survey conducted in Turkey, in March 2018, for 10 different fish species with red mullet having the highest mean concentrations in As (50.34 $\mathrm{mg} \mathrm{Kg}^{-1}$ wet weight), 209.8 times higher than that of rainbow trout [44], indicated that red mullet, a demersal fish, contains higher levels of As than other species. This species probably accumulates higher levels of toxic metals as it lives close with sediments on the sea bed and feeds on benthic organisms, causing potential carcinogenic risk to consumers. 


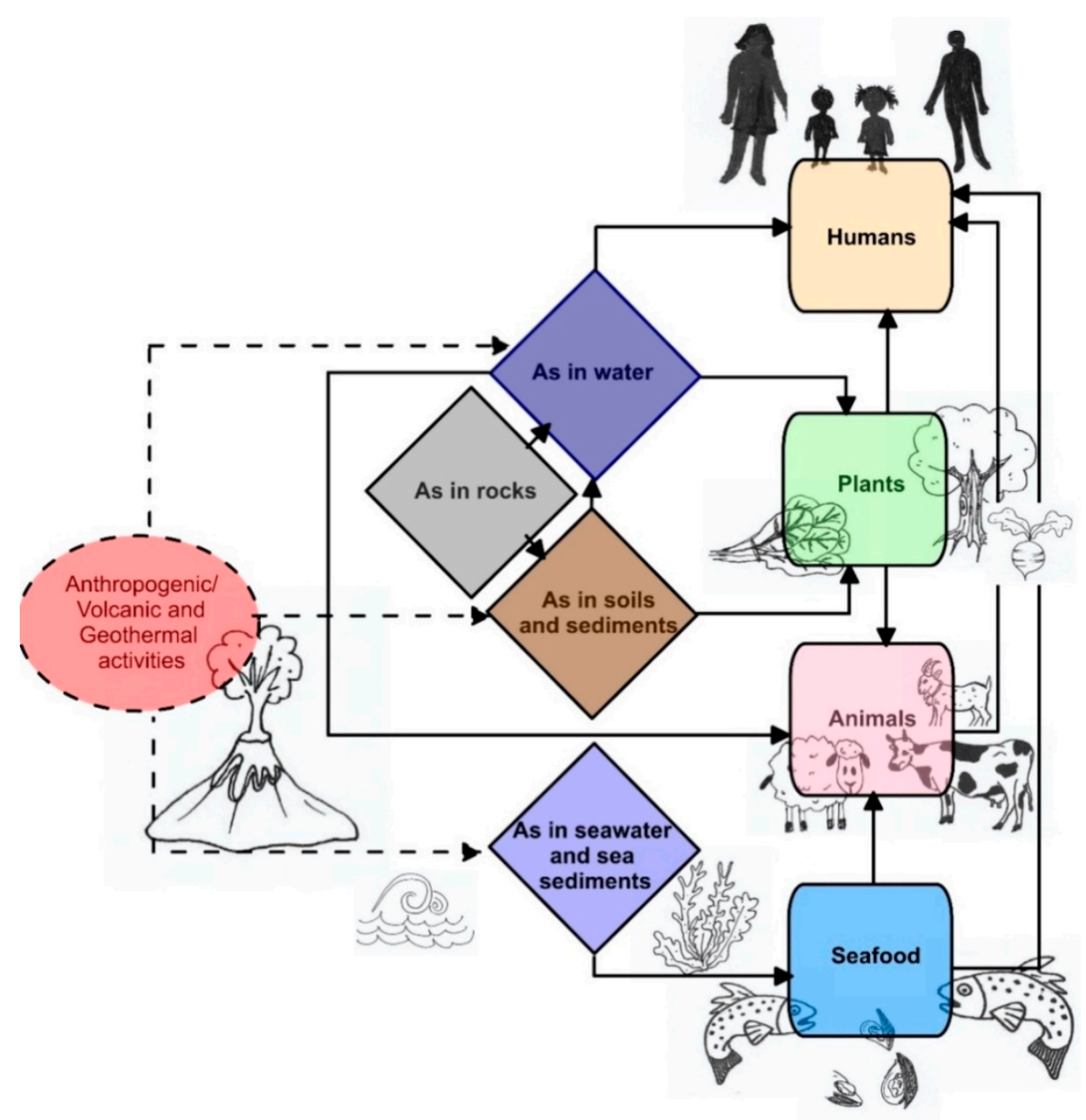

Figure 1. Schematic diagram is showing As cycle in the environment.

In the Ionian Sea in the period June-August 2003 the concentrations of As were measured in two fishes, the bluefin tuna (Thunnus thynnus) and the swordfish (Xiphias gladius) in order to investigate the presence of As in these species and the extent of the pollution in that specific marine area of Mediterranean Sea [45]. Samples were taken from the muscle tissue and the liver from 58 specimens of swordfish and 73 of bluefin tuna. It was observed that in both species the As concentrations were about twice as high in the liver than those found in the muscle tissues, while no significant difference was found in the levels of As between the two species. Especially, the concentrations range in the muscle tissue was $1.70-7.44 \mathrm{mg} \mathrm{Kg}^{-1}$ of wet weight and $1.62-5.01 \mathrm{mg} \mathrm{Kg}^{-1}$ of wet weight, and $2.58-14.81 \mathrm{mg} \mathrm{Kg}^{-1}$ of wet weight and $2.08-11.24 \mathrm{mg} \mathrm{Kg}^{-1}$ of wet weight in the liver, for the swordfish and the bluefin tuna, respectively.

\section{Sources}

The occurrence of As in groundwater and surface water is attributed to natural and anthropogenic sources, in thermal springs (geothermal water) and mining areas, with the first one being the most important reason of this issue in the environment [46].

In many volcanic areas, the volcanic glass and/or volcanic ash of rhyolitic composition that dissolves in groundwater is the main source of As. It has been noticed that in areas like Mexico, Argentina, Chile, Ethiopia, and Texas, the As is mainly released in groundwater under oxidizing conditions. This is expected as a consequence of the desorption from mineral phases at high $\mathrm{pH}$ [47]. 
Another significant source of As is the terrestrial and marine hydrothermal systems, as it is being released from shallow-sea hydrothermal vents into coastal marine environments affecting the enclosing ecosystems. In this case, As concentrations affected by the rock type as it is leached from the underlying parent rocks [48].

The sources of As into the soil are either geogenic or anthropogenic. The As may exist in the soil or be introduced by anthropogenic activities, including the application of pesticides and herbicides overlong periods [4]. The As levels in Neogene sediments of Attica (Greece) have been observed to range from 1 to $40 \mathrm{mg} \mathrm{Kg}^{-1}$, while the content in many foods ranging from 20 to $140 \mu \mathrm{g} \mathrm{Kg}^{-1}$ [1].

Singh et al. [49] reported that the major source of As in hydrosphere, pedosphere, biosphere and atmosphere is its release from As-enriched rocks and minerals. Arsenic sources include both geological (i.e., weathering of pyrite and arsenopyrite) and anthropogenic (i.e., use of agrochemicals, coal combustion, timber preservatives).

Zevenhoven et al. [27] reported that As contents in Polish coal is around $5 \mathrm{mg} \mathrm{Kg}^{-1}$, the As input to the coal-fired power plant is around $300 \mathrm{~g} \mathrm{~h}^{-1}$, of which around $1.5 \mathrm{~g} \mathrm{~h}^{-1}$ (i.e., around $0.5 \%$ ) is emitted into the atmosphere. The anthropogenic emission sources for As for Greece in 2000 from coal-fired power plants, coal fired residential heating, nonferrous metal production, and other emission sources is $1.1,0.9,1.5$ and $0.5 \mathrm{t}$, respectively; while for Cyprus from other emission sources is $0.1 \mathrm{t}$ [27].

The health effects of As on the population living near industrial areas are also noteworthy. Vimercati et al. [50,51], between January 2010 and April 2012, measured the concentration levels of specific heavy metals including inorganic As and its methylated metabolites monomethyl-arsenic acid and dimethylarsinic acid to estimate the environmental exposure to As, in samples containing urine from the industrial area of Taranto in South Italy. Companies which are located in this area include a variety of industrial processes, as a large integrated cycle steel foundry, a refinery, and a cement factory. The results, from 279 participants, showed high urinary concentrations of inorganic As and its methylated metabolite due to the operation of the above industrial plants. It is also well known that As is still used in both agriculture and industry. However, during these studies, no correlation was found between pesticide use and urinary As concentrations.

A biomonitoring study of As exposure was carried out, between 2003 and 2004, in the Ria of Huelva, a highly industrialized mining and industrial area in Southwestern Spain [52]. Arsenic was detected in urine samples of children and adolescents. The results of this study were compared with the findings of samples from children and adolescents living in less industrial areas of Andalusia in Southern Spain. Arsenic levels in both studies were within the same range reported by other biomonitoring studies regarding general youth population (children and adolescents), although young are more vulnerable to the harmful effects of toxic substances than adults. This is because children's immune and nervous systems continue to grow while being proportionately more exposed to toxic chemical substances, because they consume more water and food per unit of body weight than adults, and their respiration rate is higher. However, it should be noted that children and adolescents are not exposed to occupational threats, risks and for this reason they are particularly suitable for biomonitoring studies related to toxic element exposures.

In another case, in Southern Tunisia the exposure to As was also evaluated, detecting the concentrations range of As in human blood specimens from 350 subjects [53]. The studied area included mines and active industries. The results of the survey conducted by Khlifi et al. [53] showed that the concentration of As was $1.56 \mu \mathrm{g} \mathrm{L}{ }^{-1}$ with the levels of blood As to be positively correlated with age; while an association between the very high blood As concentrations and exposure to pesticides and wood fumes was observed.

\section{Factors}

According to Aloupi et al. [54], the occurrence of As in groundwater aquifers depends on many factors, as physicochemical properties, regional climate, geological setting, lithology and geochemistry. The processes of adsorption and desorption determine the 
mobility of As on mineral surfaces and the parameters that influence these processes include dissolved organic carbon (DOC), $\mathrm{pH}$, phosphate, carbonate, sulfate, chloride, and nitrate anions, ageing processes, mediated redox transformations and the precipitation, coprecipitation and dissolution of As with other phases, as calcite and iron (hydr)oxides [37].

\section{The Occurrence of As in Greece and Cyprus}

In many parts of the world, the USA, Mexico, Argentina, Bolivia, Chile, and other countries from South East Asia as, Cambodia, Mongolia Bangladesh, West Bengal, Vietnam, the issue of groundwater As contamination and its association with human health risk has been well studied. In Europe, and especially in Spain, Finland, Hungary, Romania, Germany and Greece, many people are exposed to As levels higher than $10 \mu \mathrm{g} \mathrm{L}^{-1}$ [25]. Table 1 shows the concentrations range of As worldwide, according to Christodoulidou et al. [55]. Greece is characterized as an As-contaminated "hot spot" [46]. Figure 2 presents the sampling locations of the Greek case study.

Table 1. Concentrations of As worldwide, according to Christodoulidou et al. [55].

\begin{tabular}{ccc}
\hline Medium & Country & Concentration \\
\hline Drinking water & Argentina & $0.3-0.8 \mu \mathrm{g} \mathrm{L}^{-1}$ \\
\hline Drinking water & Northern Chile (period 1958-1970) & $860 \mathrm{mg} \mathrm{L}^{-1}$ \\
\hline Groundwater & Eastern Croatia & $1.3-491 \mu \mathrm{g} \mathrm{L}^{-1}$ \\
\hline Groundwater & Argentina & $133-305 \mu \mathrm{g} \mathrm{L}^{-1}$ \\
\hline Groundwater & China, Huhhot Basin & $>1500 \mathrm{mg} \mathrm{L}^{-1}$ \\
\hline Rural wells & Argentina & $25-76 \mu \mathrm{g} \mathrm{L}^{-1}$ \\
\hline Urban wells & Argentina & $31-357 \mu \mathrm{g} \mathrm{L}^{-1}$ \\
\hline Wells (48\%) & Vietnam & $>50 \mu \mathrm{g} \mathrm{L}^{-1}$ \\
\hline Wells (45\%) & India (West Bengal) & $>50 \mu \mathrm{g} \mathrm{L}^{-1}$ \\
\hline Wells & Bangladesh & $<0.5$ to $3200 \mu \mathrm{g} \mathrm{L}-1$ \\
\hline Surface water & Argentina & $11-133 \mu \mathrm{g} \mathrm{L}^{-1}$ \\
\hline
\end{tabular}

Numerous studies highlight the occurrence of As in many regions in Greece, especially in Northern Greece, including the area of Thessaloniki, Chalkidiki, and eastern Thessaly. In these areas, the origin of As is the parent rocks and mineralization; while the As concentration is up to $130 \mu \mathrm{g} \mathrm{L}^{-1}$ [54]. Notably, in the Chalkidiki within the geothermal area of Nea Triglia the levels of As in groundwater, that is used for irrigation, exceed $1000 \mu \mathrm{g} \mathrm{L}^{-1}$. The use of these waters is a cause of great contamination considering that in Asia, the accumulation of As in rice has adverse health effects to many inhabitants [37]. In these Greek regions, in accordance with the Geochemical Atlas of Europe the highest As concentration in soils are also observed $\left(5-520 \mathrm{mg} \mathrm{Kg}^{-1}\right)[20,37]$. 


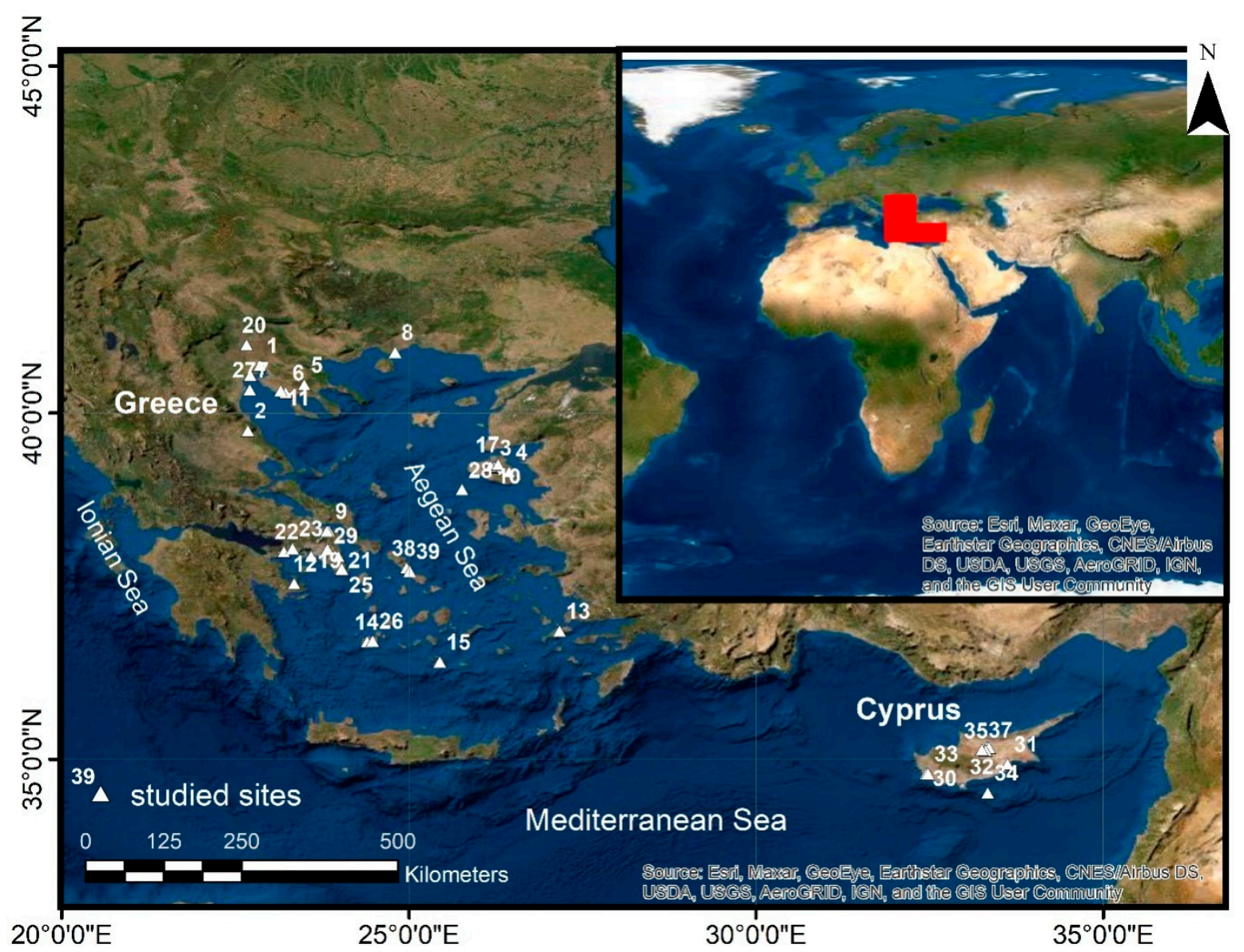

Figure 2. Map of Greece and Cyprus showing the studied sites (modified from [56]). More information and details about each site are tabulated in Table 2.

\subsection{Water}

Concerning stream waters, the highest concentration levels of As in Greece is recorded in Macedonia region [20]. In this region of Greece groundwater resources, which are mainly used as a potable water supply, showed As concentrations higher than $30 \mu \mathrm{g} \mathrm{L}{ }^{-1}$; while As contents were detected up to $70 \mu \mathrm{g} \mathrm{L}^{-1}$ in the water of Thessaloniki city. In the case of Thessaloniki city, there is a possible correlation between As speciation and U concentration especially, when U concentration increases then the ratio of As(III)/ As(tot) decreases [25].

High As contents in drinking water is a sensitive case in many regions since it is directly related to the adverse effects on human health and achievement of sustainable development goals, as introduced by Agenda 2030 [57]. Moreover, many regions worldwide suffer from As contamination caused by geochemical and weathering processes as well as anthropogenic activities $[2,25,54,58,59]$. Especially on surface and groundwater resources, more work should be done to evaluate their quality and provide a rapid method of water quality monitoring, including the Water Quality Index (WQI) approach [60]. To combat the above mentioned As related problems, water quality management incorporates efficient tools and methods for monitoring the water quality such as Water Quality Indices (WQIs) and utilizing the appropriate sources of water $[16,60,61]$. The participation of As and other potentially toxic elements in WQIs is a crucial issue since it is a challenge for stakeholders, policymakers and health practitioners in the face of poverty, human health risk, and the adverse effects of human development [61]. However, the inclusion of various parameters in WQIs and their meta-evaluation is a critical research topic [60].

In Greece, the classification of groundwater sources with high concentration levels of As includes the geothermal regions of Macedonia and especially in Chalkidiki (As 
concentrations up to $2000 \mu \mathrm{g} \mathrm{L}^{-1}$ ) and Aridaia (As concentration range 5-30 $\mu \mathrm{g} \mathrm{L}^{-1}$ ). The As water content in aquifers formed in alluvial deposits of Axios basin varied between 20 and $45 \mu \mathrm{g} \mathrm{L}^{-1}$; while in Nestos basin ranged from 15 to $20 \mu \mathrm{g} \mathrm{L}^{-1}$, which is attributed to the weathering of As rich minerals. These As rich minerals are observed close to mining activities and the regions of Eastern Thessaly (As concentration range 20-60 $\mu \mathrm{g} \mathrm{L}^{-1}$ ) [18]. Kelepertsis et al. [16] conducted a geochemical survey in Eastern Thessaly region (Greece) and recorded elevated As contents (up to $125 \mu \mathrm{g} \mathrm{L}^{-1}$ ) in groundwater which is attributed to the presence of sulphide mineralisation and hydrothermally altered zones; whereas As occurs as arsenopyrite (FeAsS) within the metamorphic rocks of the basement. Furthermore, in this area more than 5000 people are exposed to groundwater and potable water containing high levels of As (up to $125 \mu \mathrm{g} \mathrm{L}^{-1}$ ) and Sb (up to $21 \mu \mathrm{g} \mathrm{L}^{-1}$ ) [16].

Oropos-Kalamos basin (50 km north of Athens, Greece) is characterised by intensive agricultural activities and past lignite mining activities which have been stopped since 1966 but great amounts of waste produced from mining activities is still deposited in piles around suburban areas [58]. Arsenic contents in groundwater of Oropos-Kalamos basin ranged from 0.5 to $246.5 \mu \mathrm{g} \mathrm{L}-1$ are attributed to the presence of As in lignite intercalations, pile wastes in the surrounding area and abandoned lignite mining works [58,62].

In Kalloni Gulf (Lesvos island, Greece) the As ranges for groundwater, stream water, stream sediments and thermal spring water are $<0.7-88.3 \mu \mathrm{g} \mathrm{L}^{-1}, 0.4-13.2 \mu \mathrm{g} \mathrm{L}^{-1}$, 2.0-21.9 $\mathrm{mg} \mathrm{Kg}^{-1}$, and 0.4-13.2 $\mu \mathrm{g} \mathrm{L}^{-1}$, respectively [54]. In Lesvos island, the findings from groundwater sampling occasionally showed As concentrations higher than the parametric value of $10 \mu \mathrm{g} \mathrm{L}^{-1}$ given by EC [19]. Elevated As contents in groundwater were also observed in many volcanic areas [54]. A follow up study was conducted in Mandamados area (Lesvos island, Greece) which is dominated mainly by rhyolitic rocks. According to Zkeri et al. [26] the As content in groundwater of Mandamados area ranged from 1.78 to $54.7 \mu \mathrm{g} \mathrm{L}^{-1}$ with the $47 \%$ of the groundwater samples exceeding the parametric value of $10 \mu \mathrm{g} \mathrm{L}^{-1}$ provided by EC [19]. The As concentration in groundwater samples collected in the proximity of the Mandamados coast are higher than the As content in groundwater samples collected in the inland area of Mandamados [26]. The prevalent species was As(V) while species As(III) were detected in lower concentrations [26].

The results of a three-year survey which is performed in 84 boreholes from 2007 to 2009 in Cyprus showed that the As content in groundwater, in many water samples exceeds the guideline value of $10 \mu \mathrm{g} \mathrm{L}^{-1}$ established by the EC [19]. Especially, As contents in groundwater of Cyprus varied between $<0.3$ and $41 \mu \mathrm{g} \mathrm{L}^{-1}$. The highest As levels in groundwater of Cyprus were detected in the districts of Paphos $\left(26 \mu \mathrm{g} \mathrm{L}^{-1}\right)$, Larnaca (12 and $\left.13 \mu \mathrm{g} \mathrm{L}^{-1}\right)$, and Nicosia (23 and $\left.41 \mu \mathrm{g} \mathrm{L}^{-1}\right)$. A follow up research study in selected boreholes of Cyprus, revealed that the As concentrations ranged from $<0.3$ to $64.2 \mu \mathrm{g} \mathrm{L}^{-1}$. Similar As concentrations were also detected in wells of northern Greece, ranging from 3 to $74.6 \mu \mathrm{g} \mathrm{L}^{-1}$. The geochemistry and the reducing and/or oxidising conditions affected the dominant As species, with the higher redox potential Eh to favour the presence of As(III) [55]. The mean concentration of As in groundwater from eight wells which are situated close to Paphos (Cyprus) was found to be $1.3 \mu \mathrm{g} \mathrm{L}{ }^{-1}$ in samples that were collected during three sampling periods (November 2006 to October 2011) [63].

\subsection{Geothermal Activities}

The presence of As due to geothermal activities has been reported in South Aegean active volcanic arc, starting from Methana island with As concentration up to $20.5 \mathrm{mg} \mathrm{Kg}^{-1}$. It ends upon Kos island with As concentration up to $56 \mathrm{mg} \mathrm{Kg}^{-1}$. This volcanic arc, also include Milos and Santorini islands with concentration levels of 108 and $493 \mathrm{mg} \mathrm{Kg}^{-1}$, respectively [17].

In Central Macedonia, the arsenic content of ground waters that are affected by geothermal field of Katsika Mountain varied between 1000 and $4000 \mu \mathrm{g} \mathrm{L}^{-1}$, while in the coastal area ranged from 20 to $150 \mu \mathrm{g} \mathrm{L}^{-1}$. A gradual decrease in As levels was observed after mixing with cold waters of unconfined aquifers [64]. 
High As concentrations have been observed also in shallow water that originates from hydrothermal vents. On the south part of Milos island (Greece), the concentration of As ranged from 2955 to $5850 \mu \mathrm{g} \mathrm{L}^{-1}$. This is due to an existed marine shallow-water hydrothermal system, where As-rich gas is discharged in high quantities [65]. Furthermore, according to Price et al. [48], in Milos island and especially in Palaeochori and Spathi Bays, the maximum As concentration in the high and low-Cl fluids approached $39 \mu \mathrm{M}$ and up to $78 \mu \mathrm{M}$, respectively. These As concentrations are the highest observed for any submarine hydrothermal vent including mid-ocean ridge, and back-arc basin (BAB) vent fluids originated from seawater, compared with the typical As concentrations in the mid-ocean ridge $(<0.7 \mu \mathrm{M})$ and BAB fluids $(<10 \mu \mathrm{M})$ [48].

\subsection{Marine Environment}

\subsubsection{Marine Sediments}

High levels of As, ranged from 17-25 mg Kg ${ }^{-1}$, have been detected during April 1981 in the sea sediments of Northern Saronicos Gulf (Greece), which received both the wastewater effluents of the Athens area and industrial discharge of two plants that produced fertilizer and sulphuric acid [66].

Arsenic enrichments were found in all Hellenic Volcanic Arc (HVA) metalliferous sediments except for the northern side of the volcanic arc, such as the Voudia Bay, Milos, and the Kephalos Bay, Kos $[67,68]$. Chemical analysis of hydrothermal sediments collected from the shore of Santorini island, showed hydrothermal enrichments of As in the sediments compared to normal marine sediments $[59,69,70]$. It has been noticed that there is an increase of As/Fe ratios in the sediments with increasing distance from the hydrothermal vents. This is in line with the strong relation between As and Fe in Santorini submarine hydrothermal sediments [59]. Additionally, As enrichments in hydrothermal sediments were also reported for the samples collected from Methana peninsula [71] and Yali island, along the HVA [67]. The sea sediments gathered from Rivari (Milos island, HVA) showed similar geochemical characteristics, exhibiting As enrichments [72].

In Cyprus and especially in the Cilician Basin, in the northern area of the island near to Turkish mainland, the levels of As concentration were determined in sediments from three different regions in 2011. The results showed that the concentrations ranged from 3.3 to $55.4 \mathrm{mg} \mathrm{Kg}^{-1}$. It is worth noting that As concentrations were generally greater than the elemental background concentrations of $3.5 \mathrm{mg} \mathrm{Kg}^{-1}$ (dry weight) for all the studied regions. These levels are similar to other regions of the Mediterranean Sea. This contamination in most cases is due to anthropogenic origin while local anomalies should not be ruled out [13].

\subsubsection{Marine Waters}

Arsenic concentrations in hydrothermal waters of Santorini island (Greece) was found to vary between 6.6 and $16.5 \mu \mathrm{g} \mathrm{L}^{-1}$ [59], while in normal seawater was reported to be $2 \mu \mathrm{g} \mathrm{L}^{-1}$ [73]. Generally, the concentrations of As in the hydrothermal waters studied along the HVA decrease in the following order: Santorini embayments $>$ Yali Bay $>$ Thiafi Bay South $>$ Thiafi Bay North $>$ Santorini Channel $>$ Palaechori Bay $>$ Adamas Caldera $>$ Voudia Bay $>$ Kephalos Bay. Arsenic in the marine environment is strongly associated with $\mathrm{Fe}$, being scavenged from seawater by Fe oxides/hydroxides; its scavenging being more effective with increasing distance from hydrothermal vents. Thus, confirming that the presence of dissolved Fe in the hydrothermal solutions and the subsequent formation of Fe oxides/hydroxides are among the important limiting factors in the transfer of As from water to sediments $[59,68]$.

8.3.3. Factors Controlling the Spatial Variability of As in Greek Submarine Hydrothermal Sediments and Waters

It has been suggested that the significant spatial variability of As in hydrothermal sediments along the HVA is the result of the strong variability of one or more of the follow- 
ing factors: (a) the composition of rocks being leached by seawater during seawater-rock interaction processes, leading to the formation of hydrothermal solutions; (b) the variations in the temperature and pressure during seawater-rock interaction; (c) the variability of volumes of rocks being leached; $(\mathrm{d})$ the variability in the degree of mixing of the hydrothermal solutions with seawater immediately after their discharge onto the seafloor; (e) the sedimentation rates of detrital material; and (f) the prevailing $\mathrm{pH}$, Eh, temperature conditions.

\subsubsection{Effect of As on Bacteria Biomass}

Dando et al. [74] reported that faunal biomass in HVA hydrothermal sites $\left(\leq 80 \mathrm{~g} \mathrm{~m}^{-2}\right)$ is lower compared with the biomass values of other hydrothermal fields. Biomass values of $10,000 \mathrm{~g} \mathrm{~m}^{-2}$ were reported from Kuriles; while values ranging between 550 and $53,000 \mathrm{~g} \mathrm{~m}^{-2}$ were reported from mid-ocean ridges for epifauna. Since laboratory experiments showed the effect of toxic elements on bacteria it is highly probable that the low biomass found in the HVA hydrothermal sites may be at least partly related to the presence of toxic elements including As. However, to what extend the presence of As in high concentrations is responsible for the decrease of biomass is not yet known due to the antagonistic effect of other toxic metals in the sediments.

\subsection{Soil}

In Lavrion (Attica region, Greece), the concentrations of As in garden soils and house dust varied between 14,800 and $3800 \mathrm{mg} \mathrm{Kg}^{-1}$, respectively due to the polymetallic sulfide mineralization consisted of Ag-bearing galena, sphalerite, and pyrite and mining and smelting activities which produced a vast amount of toxic wastes since the ancient years [2,75]. Arsenic-polluted soils are also recorded in Cyclades islands [20]. Kampouroglou and Economou-Eliopoulos [1], studied the percentage of the incorporation of some metals in plants from rocks and soils and the possible groundwater contamination in Neogene basins of Attica. Concerning the As and other elements as $\mathrm{Pb}, \mathrm{Ni}, \mathrm{Mn}, \mathrm{Cr}, \mathrm{Ba}, \mathrm{Sb}, \mathrm{Fe}$, the bio-accumulation factor for plants, ranged from 1.5 to $7.6 \%$. It is worth noting that criteria or screening values for soil As and heavy metals have not been established yet by the Greek legislation. Alexakis [75] recorded elevated As content (up to $273 \mathrm{mg} \mathrm{Kg}^{-1}$ ) in stream sediments of East Attica region which is attributed mainly to the $\mathrm{Pb}-\mathrm{Ag}-\mathrm{Zn}$ massive sulphide mineralization of the broader area of Lavrion (Greece).

A survey carried out by Akun et al. [76] in north and south Cyprus revealed that As contents in soil ranged from 0.2 to $22.5 \mathrm{mg} \mathrm{Kg}^{-1}$. These results indicate the presence of elevated As contents in soil due to the use of herbicides and insecticides in crops.

Samples from soil, originating from 123 sampling sites, were also carried out and analysed including the determination of As in the area of Lefkosia (Nikosia) the capital of Cyprus, covering seven municipalities. Arsenic concentrations ranged below the detection limit $\left(2 \mathrm{mg} \mathrm{Kg}^{-1}\right)$ to $41.8 \mathrm{mg} \mathrm{Kg}^{-1}$. Sites containing transported weathering material derived from Pleistocene carbonate-rich terrace deposits, pouri, are identified as the cause of elevated concentrations (10-40 $\mathrm{mg} \mathrm{Kg}^{-1}$ ) which are associated with children's playgrounds, while the source of As was not identified yet [77].

Alexakis et al. [78] conducted a survey in Megara basin and reported As contents in top soil (0-20 cm depth) up to $18 \mathrm{mg} \mathrm{Kg}^{-1}$ and As concentration in subsoil (20-40 cm depth) up to $15 \mathrm{mg} \mathrm{Kg}^{-1}$. The As content in the wildfire ash layer deposited on land of Kineta (Greece) after the 2018 wildfire event and in central Evia (Greece) after the 2019 wildfire event was ranging from 4 to $16 \mathrm{mg} \mathrm{Kg}^{-1}$ [79] and from 2 to $23 \mathrm{mg} \mathrm{Kg}^{-1}$ [80], respectively; while the As concentration in the topsoil of the wildfire impacted area of central Evia was varying between 3 and $10 \mathrm{mg} \mathrm{Kg}^{-1}$ [80].

\subsection{Mines}

Alexakis and Gamvroula [62] reported for the first-time elevated levels of As in marly formations (up to $12.1 \mathrm{mg} \mathrm{Kg}^{-1}$ ), lignite intercalations (up to $226.2 \mathrm{mg} \mathrm{Kg}^{-1}$ ) and 
conglomerates (up to $34.8 \mathrm{mg} \mathrm{Kg}^{-1}$ ) in Oropos-Kalamos basin (Attica, Greece). According to Kampouroglou and Economou-Eliopoulos [81], increased levels of As in a limestone quarry were recorded in the basin of Varnavas (Attica region, Greece). In the abandoned sulfide Mathiatis mine since 1987 (Nicosia district, Cyprus), a survey was conducted in September 1999 to characterize the mineralogical hosts of As, and other heavy metals $(\mathrm{Cu}, \mathrm{Pb}, \mathrm{Zn})$ [21]. It is showed that As-containing in mine spoil and stream sediments is associated mainly with the phase of $\mathrm{Fe}(-\mathrm{Al}-\mathrm{Mg}-)-\mathrm{S}-\mathrm{O}$ and $\mathrm{Fe}(-\mathrm{Al}-\mathrm{S})-\mathrm{O}$, and less to $\mathrm{Al}(-\mathrm{Mg}-\mathrm{Fe})-\mathrm{S}-\mathrm{O}$ and $\mathrm{Mg}(-\mathrm{Al}-\mathrm{Fe})-\mathrm{S}-\mathrm{O}$ phase [21]. The high levels of $\mathrm{CaCl}_{2}$-soluble As, as $\mathrm{Zn}$ and $\mathrm{Cu}$ in the salt crusts, suggest that the release of these elements to local waters is due to the dissolution of these phases. The concentration levels of As in most of the mine spoil samples and stream sediments ranged from 10 to $220 \mathrm{mg} \mathrm{Kg}^{-1}$ [21]. From the same mine (Mathiatis mine), few years later (April 2010) soil samples were collected around the pit from the spoil heaps as well as from pyrite piles. The findings showed elevated As concentrations, ranged from levels below detection limit to levels up to $160 \mathrm{\mu g} \mathrm{Kg}^{-1}$; while acid mine drainage (AMD) which is one of the leading environmental impacts of sulfide mines was recorded. The low $\mathrm{pH}$ levels, the high concentrations of heavy metals and sulfur ions are the significant characteristics of AMD that are among the main pollution sources of soil and water resources [82].

The occurrence of As in an abandoned for 70 years gold-silver enrichment plant was also investigated in the Mitsero village (Cyprus). Soil and water samples were collected from five potentially-polluted zones in Mitsero village. Arsenic content (up to $390 \mathrm{mg}$ $\mathrm{Kg}^{-1}$ ) in soils of Mitsero village is exceeding the criteria given by Canadian $\left(12 \mathrm{mg} \mathrm{Kg}^{-1}\right)$ and the Dutch (55 mg Kg${ }^{-1}$ ) guidelines. It should be noted that $\mathrm{Fe}(\mathrm{OH})_{3}$ controls the leachability of As in soils collected from the region of tailings of Mitsero village due to the adsorption of $\mathrm{As}(\mathrm{V})$ species. The results from the analysis of two water samples from seasonal streams of Mitsero village showed elevated levels of As (80.3 and $96.5 \mu \mathrm{g} \mathrm{L}^{-1}$ ). It is evident that the extent of As contamination continues to be high due to the former metallurgical work even though they have been abandoned for many decades [83].

In an abandoned mine in Appliki copper deposit, in the ophiolite complex of Troodos mountain (Cyprus), As during microanalyses of pyrite ranged from 0.1 to $0.5 \mathrm{wt} \%$, and up to $0.2 \mathrm{wt} \%$ in chalcopyrite, according to the survey conducted by Antivachis [84].

According to a diachronic study of copper alloy artefacts produced in Cyprus (regions of Pyla-Kokkinokremos, Palaepaphos Skales and Salamis), As concentrations varied between 0.2 and $0.4 \%$ [85] which are attributed to the smelting processes of polymetallic copper ores.

\subsection{Seafood}

Seafood samples collected from the Aegean Sea has been analyzed from the determination of As, by Schaeffer et al. [86], and the results showed the presence of arsenobetaine as the predominant compound varied between 2.7 and $23.1 \mathrm{mg} \mathrm{Kg}^{-1}$ dry weight while other As species including As(III), dimethylarsinic acid, and arsenocholine were detected in trace amounts.

The total As concentration has been detected by Pell et al. [87] in an investigation that was performed at North Aegean and especially in the Thermaikos Gulf (Greece), providing data from the presence of As in dominant seaweed species from a region that affected by urban and industrial sources of pollution. The As concentrations ranged from 1.39 to $55.0 \mathrm{mg} \mathrm{Kg}^{-1}$ with Cystoseira species and Codium fragile to appear the higher total As concentrations among ten seaweed species [87].

\subsection{Bottled Water}

The presence of As in bottled water of the Greek market has been examined by Katsoyiannis et al. [18], while the results have shown that the detected As concentrations were lower than the parametric value of $10 \mu \mathrm{g} \mathrm{L}^{-1}$ established by EC [19]. Table 2 summarizes the As contents in various media in Greece. 
Table 2. Concentration of As in various media in Greece and Cyprus. (HGAFS: Hydride generation atomic fluorescence spectrometer, AAS-MHS: Atomic absorption spectroscopy with a mercury hydride system, HGAAS: Hydride generation atomic absorption spectrometry, GFAAS: Graphite furnace atomic absorption spectroscopy, ICP-MS: Inductively coupled plasma-mass spectrometry, ICP-OES: Inductively coupled plasma optical emission spectroscopy, INAA: Instrumental neutron activation analysis, ICP-AES: Inductively coupled plasma atomic emission spectrometry, HR-ICP-MS: High resolution inductive coupled plasma-mass spectrometer, ICP-TOFMS: Inductively coupled plasma time-of-flight (TOF) mass spectrometer, DL: Detection limit, n.d.: no data).

\begin{tabular}{|c|c|c|c|c|c|c|}
\hline Medium & $\begin{array}{l}\text { Location Number } \\
\text { (as Shown in } \\
\text { Figure 2) }\end{array}$ & $\begin{array}{l}\text { Location } \\
\text { Name }\end{array}$ & Sampling Period & Detection Method (DL) & Concentration & Ref. \\
\hline Groundwater & 1 & Thessaloniki & 2016 & HGAFS & $>70 \mu \mathrm{g} \mathrm{L}^{-1}$ & [25] \\
\hline Groundwater & 2 & Eastern Thessaly & $2003-2004$ & AAS-MHS & $1-125 \mu \mathrm{g} \mathrm{L}^{-1}$ & [16] \\
\hline Groundwater & 3 & Lesvos Island & 2005 & $\begin{array}{c}\text { HGAAS-GFAAS } \\
\left(0.7 \mu \mathrm{g} \mathrm{L}^{-1} \text { for dissolved As, }\right. \\
\left.0.1 \mu \mathrm{g} \mathrm{L}^{-1} \text { for particulate As }\right)\end{array}$ & $<0.7-88.3 \mu \mathrm{g} \mathrm{L}^{-1}$ & [54] \\
\hline Groundwater & 4 & $\begin{array}{l}\text { Mandamados } \\
\text { Lesvos island, }\end{array}$ & 2010-2011 & $\begin{array}{c}\text { ICP-MS } \\
\left(0.1 \mu \mathrm{g} \mathrm{L}^{-1}\right)\end{array}$ & $1.78-54.7 \mu \mathrm{g} \mathrm{L}^{-1}$ & [26] \\
\hline $\begin{array}{l}\text { Groundwater (for } \\
\text { irrigation use) }\end{array}$ & 5 & $\begin{array}{c}\text { Chalkidiki, } \\
\text { Northern Greece }\end{array}$ & n.d. & n.d. & $>130 \mu \mathrm{g} \mathrm{L}^{-1}$ & [54] \\
\hline $\begin{array}{l}\text { Groundwater (for } \\
\text { irrigation use) }\end{array}$ & 6 & $\begin{array}{c}\text { Nea Triglia, } \\
\text { Chalkidiki, } \\
\text { Northern Greece }\end{array}$ & 2008-2009 & ICP-MS & $>1000 \mu \mathrm{g} \mathrm{L}^{-1}$ & [37] \\
\hline Groundwater & 7 & $\begin{array}{c}\text { Axios basin, } \\
\text { Northern Greece }\end{array}$ & n.d. & n.d. & $20-45 \mu \mathrm{g} \mathrm{L}^{-1}$ & [18] \\
\hline Groundwater & 8 & $\begin{array}{l}\text { Nestos basin, } \\
\text { Northern Greece }\end{array}$ & n.d. & n.d. & $15-20 \mu \mathrm{g} \mathrm{L}^{-1}$ & [18] \\
\hline Groundwater & 9 & $\begin{array}{l}\text { Oropos-Kalamos } \\
\text { basin, North Attica }\end{array}$ & 2008 & $\begin{array}{c}\text { ICP-MS } \\
\left(0.5 \mu \mathrm{g} \mathrm{L}^{-1}\right)\end{array}$ & $0.5-246.5 \mu \mathrm{g} \mathrm{L}^{-1}$ & [58] \\
\hline Stream water & 10 & $\begin{array}{l}\text { Lesvos Island, } \\
\text { Kalloni Gulf }\end{array}$ & 2005 & $\begin{array}{c}\text { HG-AAS } \\
\left(0.7 \mu \mathrm{g} \mathrm{L}^{-1} \text { for dissolved, }\right. \\
\left.0.1 \mu \mathrm{g} \mathrm{L}^{-1} \text { for particulate As }\right)\end{array}$ & $0.4-13.2 \mu \mathrm{g} \mathrm{L}^{-1}$ & [54] \\
\hline $\begin{array}{l}\text { Geothermal } \\
\text { groundwater }\end{array}$ & 11 & Chalkidiki & n.d. & n.d. & $>2000 \mu \mathrm{g} \mathrm{L}^{-1}$ & [18] \\
\hline Geothermal water & 12 & Methana island & n.d. & n.d. & $>20.5 \mathrm{mg} \mathrm{L}^{-1}$ & [18] \\
\hline Geothermal water & 13 & Kos island & n.d. & n.d. & $56 \mathrm{mg} \mathrm{L}^{-1}$ & [18] \\
\hline Geothermal water & 14 & Milos island & n.d. & n.d. & $108 \mathrm{mg} \mathrm{L}^{-1}$ & [18] \\
\hline Geothermal water & 15 & Santorini island & n.d. & n.d. & $493 \mathrm{mg} \mathrm{L}^{-1}$ & [18] \\
\hline $\begin{array}{c}\text { Thermal springs } \\
\text { water }\end{array}$ & 16 & $\begin{array}{l}\text { Kalloni Gulf, Lesvos } \\
\text { island }\end{array}$ & 2005 & $\begin{array}{c}\text { HG-AAS } \\
\left(0.7 \mu \mathrm{g} \mathrm{L}^{-1} \text { for dissolved, }\right. \\
\left.0.1 \mu \mathrm{g} \mathrm{L}^{-1} \text { for particulate As }\right)\end{array}$ & $0.4-13.2 \mu \mathrm{g} \mathrm{L}^{-1}$ & [54] \\
\hline Stream sediment & 17 & $\begin{array}{l}\text { Kalloni Gulf, Lesvos } \\
\text { island }\end{array}$ & 2005 & HG-AAS & $2.0-22 \mathrm{mg} \mathrm{Kg}^{-1}$ & [54] \\
\hline Stream sediment & 18 & East Attica & 2006-2007 & $\begin{array}{c}\text { ICP-MS } \\
\left(1 \mathrm{mg} \mathrm{Kg}^{-1}\right)\end{array}$ & $8-273 \mathrm{mg} \mathrm{Kg}^{-1}$ & [75] \\
\hline Sediment & 19 & $\begin{array}{l}\text { Northern Saronicos } \\
\text { Gulf }\end{array}$ & 1981 & INAA & $17-25 \mathrm{mg} \mathrm{Kg}^{-1}$ & [66] \\
\hline Soil & 20 & Northern Greece & 2008-2009 & ICP-MS & $5-520 \mathrm{mg} \mathrm{Kg}^{-1}$ & [37] \\
\hline Garden soil & 21 & Lavrion, Attica & n.d. & n.d. & $>14,800 \mathrm{mg} \mathrm{Kg}^{-1}$ & [2] \\
\hline Wildfire ash & 22 & Kineta, West Attica & 2018 & $\begin{array}{c}\text { ICP-AES } \\
\left(2 \mathrm{mg} \mathrm{Kg}^{-1}\right)\end{array}$ & $4-16 \mathrm{mg} \mathrm{Kg}^{-1}$ & [79] \\
\hline Soil & 23 & Megara basin & 2010 & $\begin{array}{c}\text { ICP-MS } \\
\left(5 \mathrm{mg} \mathrm{Kg}^{-1}\right)\end{array}$ & $5-18 \mathrm{mg} \mathrm{Kg}^{-1}$ & [78] \\
\hline Bulk lignite & 24 & $\begin{array}{l}\text { Oropos-Kalamos } \\
\text { basin, Attica }\end{array}$ & 2008 & $\begin{array}{c}\text { ICP-MS } \\
\left(0.1 \mathrm{mg} \mathrm{Kg}^{-1}\right)\end{array}$ & $226.2 \mathrm{mg} \mathrm{Kg}^{-1}$ & [62] \\
\hline House dust & 25 & Lavrion, Attica & & n.d. & $>3800 \mathrm{mg} \mathrm{Kg}^{-1}$ & [2] \\
\hline Groundwater & 26 & Milos island & 2009-2010 & $\begin{array}{l}\text { HR-ICP-MS } \\
\left(8-155 \text { ng L }^{-1}\right)\end{array}$ & $2955-5850 \mu \mathrm{g} \mathrm{L}^{-1}$ & [65] \\
\hline Seaweed species & 27 & Thermaikos Gulf & 2007 & $\begin{array}{c}\text { LC-ICP-MS } \\
{\left[0.01 \mathrm{mg} \mathrm{Kg}^{-1} \text { for } \mathrm{As}(\mathrm{III}),\right.} \\
\left.0.03 \mathrm{mg} \mathrm{Kg}^{-1} \text { for } \mathrm{As}(\mathrm{V})\right]\end{array}$ & $1.39-55.0 \mathrm{mg} \mathrm{Kg}^{-1}$ & [87] \\
\hline
\end{tabular}


Table 2. Cont.

\begin{tabular}{|c|c|c|c|c|c|c|}
\hline Medium & $\begin{array}{l}\text { Location Number } \\
\text { (as Shown in } \\
\text { Figure 2) }\end{array}$ & $\begin{array}{l}\text { Location } \\
\text { Name }\end{array}$ & Sampling Period & Detection Method (DL) & Concentration & Ref. \\
\hline Seafood & 28 & Aegean Sea & n.d. & $\begin{array}{c}\text { ICP-TOFMS } \\
\left(0.385 \mathrm{mg} \mathrm{Kg}^{-1}\right)\end{array}$ & $2.8-34 \mathrm{mg} \mathrm{Kg}^{-1}$ & [86] \\
\hline Bottled water & 29 & Greece & n.d. & n.d. & $<10 \mu \mathrm{g} \mathrm{L}^{-1}$ & [18] \\
\hline Groundwater & 30 & Paphos, Cyprus & 2007-2009 & $\begin{array}{c}\text { ICP-MS } \\
\left(0.3 \mu \mathrm{g} \mathrm{L}^{-1}\right)\end{array}$ & $26 \mu \mathrm{g} \mathrm{L}^{-1}$ & [55] \\
\hline Groundwater & 31 & Larnaca, Cyprus & 2007-2009 & $\begin{array}{c}\text { ICP-MS } \\
\left(0.3 \mu \mathrm{g} \mathrm{L}^{-1}\right)\end{array}$ & $12-13 \mu \mathrm{g} \mathrm{L}^{-1}$ & [55] \\
\hline Groundwater & 32 & Lefkosia, Cyprus & 2007-2009 & $\begin{array}{c}\text { ICP-MS } \\
\left(0.3 \mu \mathrm{g} \mathrm{L}^{-1}\right)\end{array}$ & $23-41 \mu \mathrm{g} \mathrm{L}^{-1}$ & [55] \\
\hline Groundwater & 33 & Paphos, Cyprus & 2006-2011 & n.d. & $1.3 \mu \mathrm{g} \mathrm{L}^{-1}$ & [63] \\
\hline Sea sediment & 34 & $\begin{array}{l}\text { Cicilian basin, } \\
\text { Cyprus }\end{array}$ & 2011 & ICP-MS & $3.3-55.4 \mathrm{mg} \mathrm{Kg}^{-1}$ & [13] \\
\hline Soil & 35 & Cyprus & n.d. & n.d. & $0.2-22.5 \mathrm{mg} \mathrm{Kg}^{-1}$ & [76] \\
\hline Soil & 36 & Lefkosia, Cyprus & n.d. & $\begin{array}{c}\text { ICP-MS } \\
\left(2 \mathrm{mg} \mathrm{Kg}^{-1}\right)\end{array}$ & $<2-41.8 \mathrm{mg} \mathrm{Kg}^{-1}$ & [77] \\
\hline Soil & 37 & $\begin{array}{l}\text { Mitsero, Lefkosia, } \\
\text { Cyprus }\end{array}$ & 2012 & ICP-OES & $390 \mathrm{mg} \mathrm{Kg}^{-1}$ & [83] \\
\hline $\begin{array}{l}\text { Wildfire impacted } \\
\text { soil }\end{array}$ & 38 & Central Evia, Greece & 2019 & $\begin{array}{c}\text { ICP-AES } \\
\left(2 \mathrm{mg} \mathrm{Kg}^{-1}\right)\end{array}$ & $3-10 \mathrm{mg} \mathrm{Kg}^{-1}$ & {$[80]$} \\
\hline Wildfire ash & 39 & Central Evia, Greece & 2019 & $\begin{array}{c}\text { ICP-AES } \\
\left(2 \mathrm{mg} \mathrm{Kg}^{-1}\right)\end{array}$ & $2-23 \mathrm{mg} \mathrm{Kg}^{-1}$ & {$[80]$} \\
\hline
\end{tabular}

\section{Igeo Assessment}

The $I_{\text {geo }}$ classes for As in Greece ranges from practically uncontaminated to extremely contaminated (Figure 3); while in Cyprus varies between practically uncontaminated and heavily contaminated. The higher Igeo classes were observed in Northern Greece and Attica region. In Cyprus, the higher $I_{\text {geo }}$ class was recorded in Mitsero village (Lefkosia).

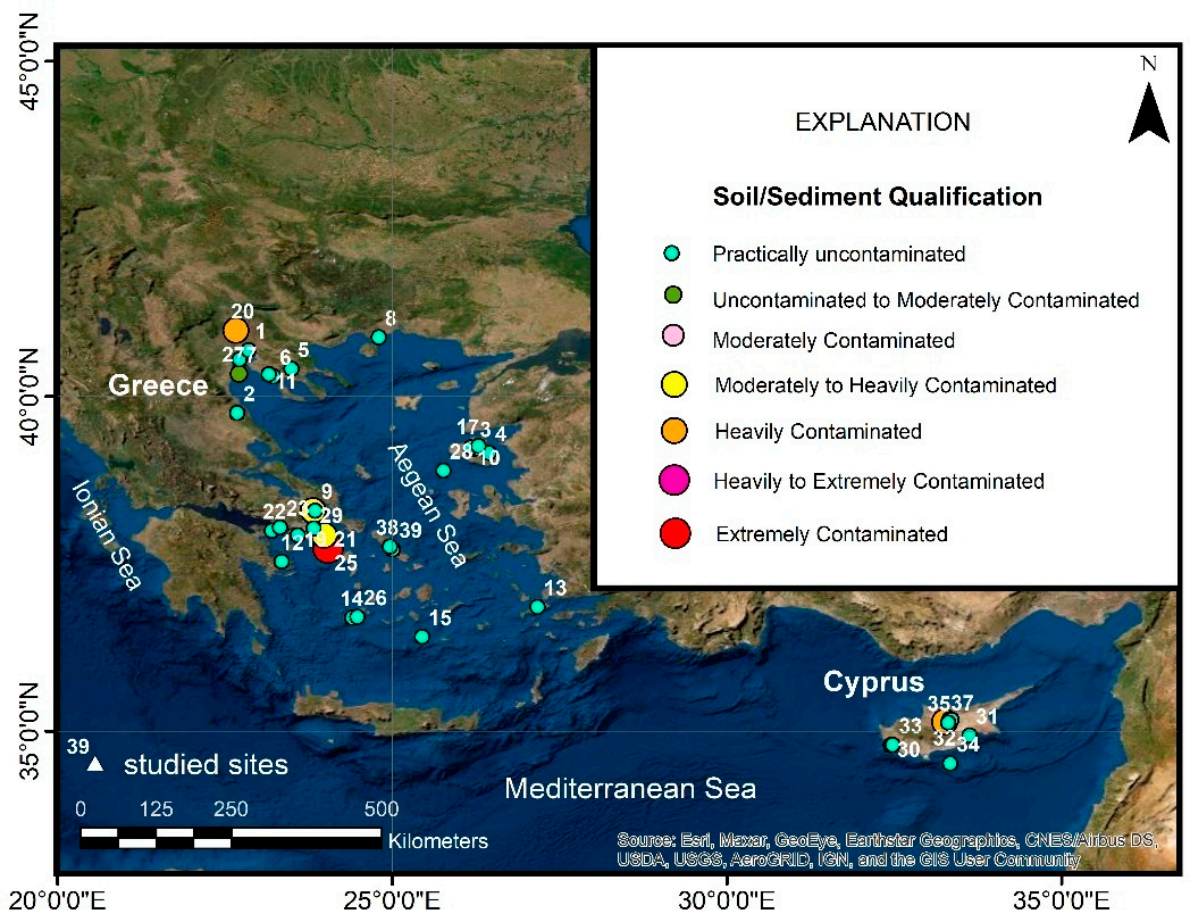

Figure 3. Spatial distribution of $I_{\text {geo }}$ classes for As in Greece and Cyprus (modified from [56]). 


\section{Removal of As from Water}

Various methods, conventional and advanced, have been proposed for the removal of As from water, including coagulation-flocculation, oxidation, ion-exchange, adsorption, and membrane processes. Of the above conventional methods, adsorption is considered one of the most effective due to the efficiency, simplicity, and availability of many different adsorbent mediums [88].

The membrane processes are considered an interesting alternative to the conventional methods considering their many benefits, but few are the applications on natural Ascontaminated groundwaters. Figoli et al. $[89,90]$ analyzed the efficiency of two commercial nanofiltration (NF) membranes in terms of As rejection and water production, also as function of the feed composition by testing three contaminated groundwaters with As contents ranging from 59 to $435 \mu \mathrm{g} \mathrm{L}^{-1}$. The authors compared their satisfactory results with those reported in the literature providing a useful data collection to identify suitable NF membranes to be applied in similar contaminated sites.

Sazakli et al. [88] developed a method in Greece, using adsorption on granular ferric oxide, to remove effectively $\mathrm{As}$ and $\mathrm{Sb}$ from drinking water in order to make it safer for human consumption. The results of this technique showed that the application of this remediation technique can be a good prospect for the removal of both As and $\mathrm{Sb}$ from drinking water, without the adsorption of one element being affected by the other.

Azamat et al. [91] used molybdenum disulfide $\left(\mathrm{MoS}_{2}\right)$ nanosheet membrane, with an appropriate hourglass shape pore in its surface, to remove As from contaminated aqueous solution. This nanostructure membrane with three-atom thick is a new water pollutant separator with unique properties, resulting in high As rejection rates under varying applied pressures. The water molecules can pass through this device with ease flux, preventing the entry of As ions through the pore in a more efficient way than the conventional filtration membranes.

Elson et al. [92] removed $\mathrm{As}(\mathrm{V})$ from groundwaters using a mixture of chitosan/chitin, a poly- $N$-acetyl-glucosamine which is $10-15 \%$ deacetylated. This potential agent was capable to remove certain polyoxy-anions including $\mathrm{As}(\mathrm{V})$ from water samples under neutral conditions of $\mathrm{pH}$ as the bonding between As and polymers involved more than simple ion-exchange.

Garrido Hoyos et al. [93] applied laboratory tests in order to design a full-scale water plant for As removal from groundwater (As contents up to $0.1671 \mathrm{mg} \mathrm{L}^{-1}$ ) in Mixco Municipality (Guatemala). The flow diagram of the As removal plant designed by Garrido Hoyos et al. [93] includes the following processing units: pre-oxidation, regulation of $\mathrm{pH}$, coagulation, flocculation, sedimentation, filtration pressure filters, disinfection, and storage. The best results (96.80\%) of As removal from groundwater in Mixco Municipality were obtained for the configuration which uses clinoptilolite filter, resulting in $0.005 \mathrm{mg} \mathrm{As} \mathrm{L}^{-1}$.

Groundwater exploitation in combination with rainwater harvesting are employed for a portion of the year in Bangladesh as an option to alleviate the challenges of decreasing the body-burden of As from groundwater [94].

Ojemaye et al. [95] employed imine functionalized magnetic nanoparticles to aqueous solutions for the removal of As(III) and concluded that these magnetic nanoparticles are a good contender as a potential adsorbent for the removal of As(III) from aqueous solutions without separation difficulty.

Liang et al. [96] applied a novel adsorbent to remove As from polluted water. The novel adsorbent was prepared by loading cerium and manganese oxide onto wheat strawmodified biochar. Liang et al. [96] concluded that wheat straw-modified biochar is a promising adsorbent to uptake $\mathrm{As}(\mathrm{V})$ from polluted water and has great potential in the remediation of As contaminated environment.

Larroca et al. [97] proposed a fuzzy control strategy embedded for removing inorganic As from synthetic underground water in a treatment plantprototype. The experiments used synthetic Bangladesh groundwater enriched with both As(III) and $\mathrm{As}(\mathrm{V})$ concentration of $200 \mu \mathrm{g} \mathrm{L}{ }^{-1}$ [97]. Larocca et al. [97] revealed that the plant prototype treated effectively 
the water and resulted in $\mathrm{As}(\mathrm{III})$ and $\mathrm{As}(\mathrm{V})$ contents lower than the limit of $10 \mu \mathrm{g} \mathrm{L}{ }^{-1}$ established by WHO.

$\mathrm{Xu}$ et al. [98] applied batch sorption experiments to study the removal of As from aqueous solutions with high salinity. Drinking water treatment solids were used to remove As from reverse osmosis concentrates [98]. Each gm of solid derived from this treatment process is calculated to remove up to $170 \mathrm{mg}$ of As [98]. Khan et al. [99] optimized the As removal process using central composite design based on response surface methodology. The removal of As around $95 \%$ was rapidly attained in an electrocoagulation reactor for optimized conditions having a $\mathrm{pH}$ of 7 and $10 \mathrm{mg} \mathrm{L}^{-1}$ initial As concentration.

Bae et al. [100] explored the potential for the removal of As from water using a mesoporous iron oxide. In the $\mathrm{pH}$ varying between 5 and 9, the adsorption of As(III) and $\mathrm{As}(\mathrm{V})$ was studied. According to Bae et al. [100], the removal rate of $\mathrm{As}(\mathrm{III})$ and $\mathrm{As}(\mathrm{V})$ has the highest adsorption efficiency; while the adsorption efficiency of mesoporous iron oxide was preserved at around $100 \%$ for given regeneration-adsorption cycles.

Nam et al. [101] used renewable coffee wastes as an adsorbent to extract As from wastewater. Nam et al. [101] recorded a maximum absorption concentration of $6.44 \mathrm{mg}$ As $\mathrm{L}^{-1}$ on $1 \mathrm{gm}$ of coffee grounds at $1.00 \mathrm{mM}$ of As solution.

Serrano et al. [102] used sulfate reducing bacteria to remove As and other heavy metals from acid mine drainage; while batch experiments showed As removal of up to $73 \%$.

Alkhudhiri et al. [103] examined the removal of As, among other elements, from synthetic industrial wastewater samples in various concentrations by air gap membrane distillation and concluded that it is a promising and cost-effective method. Ogata et al. [104] prepared complex nickel-aluminum and nickel-aluminum-zirconium hydroxides for the removal of As(III) from aqueous solutions. According to Ogata et al. [104] the adsorption capacity of As(III) on nickel-aluminum and nickel-aluminum-zirconium hydroxides is 9.3 and $15.3 \mathrm{mg} \mathrm{L}^{-1}$, respectively.

\section{Conclusions}

Arsenic is characterized as highly toxic in its inorganic form and has been recognized as carcinogenic even at deficient concentration levels. This article provides an overview of contamination by As in Greece and Cyprus in various environments. The most important reason for the As occurrence in the environment is the geogenic sources. Greece is characterized as an As-contaminated "hot spot". The highest As concentrations in groundwater and stream water of Greece were recorded in the Macedonia region. The variation of As concentration recorded in various areas of Greece is attributed to geological factors. However, high As contents are recorded in Lesvos island in the Northern Aegean and in the HVA, in the southern Aegean, in submarine hydrothermal sediments and waters. In Cyprus, As contents in groundwater are higher than the parametric value of $10 \mu \mathrm{g} \mathrm{L}^{-1}$ established by the EC. High As levels have been detected in the bottom sea sediments of the Saronicos Gulf (Attica, Greece). The estimation of $\mathrm{I}_{\text {geo }}$ for As in Greece and Cyprus revealed that the $\mathrm{I}_{\text {geo }}$ classes in Greece varies between practically uncontaminated and extremely contaminated and in Cyprus ranges from practically uncontaminated to heavily contaminated. The mixed sulphide-oxide $\mathrm{Pb}$ and $\mathrm{Zn}$ ore mining operations and the smelting since antiquity are responsible for the soil pollution in Attica (Lavrion) and Cyclades islands in Southern Aegean. In Cyprus, the concentration of As in soil and sediment samples collected from a mining area were recorded in high levels. In the area of Northern Aegean, As has also been detected in seafood samples. The presence of As in bottled water in Greece is lower than the corresponding parametric value established by EC. Concerning the removal of As from water, various methods have been proposed, including adsorption on granular ferric oxide, on molybdenum disulfide $\left(\mathrm{MoS}_{2}\right)$ nanostructure membrane even the use of a mixture of chitosan/chitin, with very satisfactory results. The systematic monitoring and the development of efficient techniques for the removal of As should be continued in Greece and Cyprus, taking seriously the adverse effects of As on both human health and environment contamination. 
Author Contributions: Conceptualization: S.P.V.; methodology: S.P.V., S.K.G., D.E.A.; software, map production, figures development: D.E.A.; validation, formal analysis, investigation: S.P.V., S.K.G., and D.E.A.; resources: S.P.V. and S.K.G.; data curation: S.K.G. and D.E.A.; writing-original draft preparation: S.K.G.; writing-review and editing: S.K.G. and D.E.A.; supervision: S.P.V. All authors have read and agreed to the published version of the manuscript.

Funding: This research received no external funding.

Institutional Review Board Statement: Not applicable.

Informed Consent Statement: Not applicable.

Data Availability Statement: Data is contained within the article.

Acknowledgments: The authors would like to thank Athina Mela, for designing and producing the clipart shown on schematic diagram depicting the As cycle in the environment.

Conflicts of Interest: The authors declare no conflict of interest.

\section{References}

1. Kampouroglou, E.E.; Economou-Eliopoulos, M. Assessment of arsenic and associated metals in the soil-plant-water system in neogene basins of Attica, Greece. Catena 2017, 150, 206-222. [CrossRef]

2. Mandal, B.K.; Suzuki, K.T. Arsenic round the world: A review. Talanta 2002, 58, 201-235. [CrossRef]

3. Sanchez-Rodas, D.; de la Campa, A.M.S.; Alsioufi, L. Analytical approaches for arsenic determination in air: A critical review. Anal. Chim. Acta 2015, 898, 1-18. [CrossRef] [PubMed]

4. Arslan, B.; Djamgoz, M.B.A.; Akun, E. Arsenic: A review on exposure pathways, accumulation, mobility and transmission into the human food chain. Rev. Environ. Contam. Toxicol. 2017, 243, 27-51. [PubMed]

5. Varnavas, S.P.; Salomons, W.; Förstner, U.; Kersten, M.; Brill, J.; Loizides, L.; Golik, A. Environmental contamination processes in the Limni mine area Cyprus. In Proceedings of the 6th International Conference on Contamination, Edinburgh, UK, 10-12 October 1994; Varnavas, S.P., Ed.; CEP Consultants Ltd.: Blackpool, UK, 1994; pp. 28-34.

6. Varnavas, S.P.; Forstner, U.; Calmano, W. Environmental assessment and human health in a highly metal polluted coastal zone associated with toxic solid waste. The need of immediate action. In Proceedings of the 7th International Conference on Environmental Science and Technology, Ermoupolis, Greece, 3-6 September 2001; pp. 903-908.

7. Christou, A.; Theologides, C.P.; Costa, C.; Kalavrouziotis, I.K.; Varnavas, S.P. Assessment of toxic heavy metals concentrations in soils and wild and cultivated plant species in Limni abandoned copper mining site, Cyprus. J. Geochem. Explor. 2017, 178, 16-22. [CrossRef]

8. Hadjipanagiotou, C.; Christou, A.; Zissimos, A.M.; Hatzitheodoridis, E.; Varnavas, S.P. Contamination of stream waters, sediments, and agricultural soil in the surroundings of an abandoned copper mine by potentially toxic elements and associated and environmental and potential human health derived risks. A case study from Agrokipia, Cyprus. Environ. Sci. Pollut. Res. 2020. [CrossRef]

9. Varnavas, S.P.; Panagos, A.G. Mesozoic metalliferous sediments from the ophiolites of Ermioni (Greece); analogue to recent mid-ocean ridge ferromanganese deposits. Chem. Geol. 1984, 42, 227-242. [CrossRef]

10. Varnavas, S.P.; Panagos, A.G.; Philippakis, S. On the metallogenesis of the Hermioni area, Greece. Mesozonic mid-ocean ridge deposits. Geol. Carpathica 1985, 36, 219-233.

11. Robertson, A.F.; Varnavas, S.P.; Panagos, A.G. Ocean ridge origin and tectonic setting of Mesozoic sulphide and oxide deposits of the Argolis Peninsula of the Peloponnesus, Greece. Sed. Geol. 1987, 53, 1-32. [CrossRef]

12. Varnavas, S.P.; Panagos, A.G.; Kritsotakis, K.G. Environmental impact of mining activities on the Hermioni area Greece. In Environmental Contamination; Vernet, J.P., Ed.; Elsevier: Amsterdam, The Netherlands, 1993; pp. 119-146.

13. Duman, M.; Kucuksezgin, F.; Atalar, M.; Akcali, B. Geochemistry of the northern Cyprus (NE Mediterranean) shelf sediments: Implications for anthropogenic and lithogenic impact. Mar. Pollut. Bull. 2012, 64, 2245-2250. [CrossRef]

14. Muller, G. Schwermetalle in den Sedimenten des Rheins-Veranderungenseit 1971. Umschau 1979, 79, 778-783.

15. Turekian, K.K.; Wedepohl, K.H. Distribution of the elements in some major units of the Earth's crust. Geol. Soc. Am. Bull. 1961, 72, 175-192. [CrossRef]

16. Kelepertsis, A.; Alexakis, D.; Skordas, K. Arsenic, antimony and other toxic elements in the drinking water of Eastern Thessaly in Greece and its possible effects on human health. Environ. Geol. 2006, 50, 76-84. [CrossRef]

17. Zaspalis, V.; Pagana, A.; Sklari, S. Arsenic removal from contaminated water by iron oxide sorbents and porous ceramic membranes. Desalination 2007, 217, 167-180. [CrossRef]

18. Katsoyiannis, I.A.; Mitrakas, M.; Zouboulis, A.I. Arsenic occurrence in Europe: Emphasis in Greece and description of the applied full-scale treatment plants. Desalin. Water Treat. 2015, 54, 2100-2107. [CrossRef]

19. EC (European Community) Council. Directive 98/83/EC Directive of the European Parliament on the quality of water intended for human consumption. The European Parliament and the Council of the European Union. Off. J. 1998, L330, 32-54. 
20. Gamaletsos, P.; Godelitsas, A.; Dotsika, E.; Tzamos, E.; Göttlicher, J.; Filippidis, A. Geological sources of As in the environment of Greece: A review. In Threats to the Quality of Groundwater Resources: Prevention and Control; Scozzari, A., Dotsika, E., Eds.; The Handbook of Environmental Chemistry; Springer: Berlin/Heidelberg, Germany, 2013; Volume 40, pp. 77-113.

21. Hudson-Edwards, K.A.; Edwards, S. Mineralogical controls on storage of $\mathrm{As}, \mathrm{Cu}, \mathrm{Pb}$ and $\mathrm{Zn}$ at the abandoned Mathiatis massive sulphide mine, Cyprus. Mineral. Mag. 2005, 69, 695-706. [CrossRef]

22. Matschullat, J. Arsenic in the geosphere-A review. Sci. Total Environ. 2002, 249, 297-312. [CrossRef]

23. Vaxevanidou, K.; Giannikou, S.; Papassiopi, N. Microbial arsenic reduction in polluted and unpolluted soils from Attica, Greece. J. Hazard. Mater. 2012, 241-242, 307-315. [CrossRef]

24. Gamaletsos, P.N.; Kalatha, S.; Godelitsas, A.; Economou-Eliopoulos, M.; Göttlicher, J.; Steininger, R. Arsenic distribution and speciation in the bauxitic Fe-Ni-laterite ore deposit of the Patitira mine, Lokris area (Greece). J. Geochem. Explor. 2018, 194, 189-197. [CrossRef]

25. Katsoyiannis, I.A.; Hug, S.J.; Ammann, A.; Zikoudi, A.; Hatziliontos, C. Arsenic speciation and uranium concentrations in drinking water supply wells in Northern Greece: Correlations with redox indicative parameters and implications for groundwater treatment. Sci. Total Environ. 2007, 383, 128-140. [CrossRef] [PubMed]

26. Zkeri, E.; Aloupi, M.; Gaganis, P. Seasonal and spatial variation of arsenic in groundwater in a rhyolithic volcanic area of Lesvos Island, Greece. Environ. Monit. Assess. 2018, 190, 44. [CrossRef] [PubMed]

27. Zevenhoven, R.; Mukherjee, A.B.; Bhattacharya, P. Arsenic flows in the environment of the European Union: A synoptic review. In Arsenic in Soil and Groundwater Environment: Trace Metals and Other Contaminants in the Environment; Bhattacharya, P., Mukherjee, A.B., Bundschuh, J., Zevenhoven, R., Loeppert, R.H., Eds.; Elsevier: Amsterdan, The Netherlands, 2007; Volume 9, pp. 527-547.

28. Devesa, V.; Velez, D.; Montoro, R. Effect of thermal treatments on arsenic species contents in food. Food Chem. Toxicol. 2008, 46, 1-8. [CrossRef] [PubMed]

29. Abdul, K.S.; Jayasinghe, S.S.; Chandana, E.P.; Jayasumana, C.; De Silva, P.M. Arsenic and human health effects: A Review. Environ. Toxicol. Pharmacol. 2015, 40, 828-846. [CrossRef]

30. Chung, J.Y.; Yu, S.D.; Hong, Y.S. Environmental source of arsenic exposure. J. Prev. Med. Public Health 2014, 47, 253-257. [CrossRef] [PubMed]

31. Anawar, H.M.; Akai, J.; Mihaljevič, M.; Sikder, A.M.; Ahmed, G.; Tareq, S.M.; Rahman, M.M. Arsenic contamination in groundwater of Bangladesh: Perspectives on geochemical, microbial and anthropogenic issues. Water 2011, 3, 1050-1076. [CrossRef]

32. Bhattacharya, P.; Mukherjee, A.B.; Bundschuh, J.; Zevenhoven, R.; Loeppert, R.H. (Eds.) Arsenic in Soil and Groundwater Environment. Biogeochemical Interactions, Health Effects and Remediation, 1st ed.; Elsevier: Amsterdam, The Netherlands, 2007.

33. Chakraborti, D.; Singh, S.K.; Rahman, M.M.; Dutta, R.N.; Mukherjee, S.C.; Pati, S.; Kar, P.B. Groundwater arsenic contamination in the Ganga River basin: A future health danger. J. Environ. Res. Public Health 2018, 15, 180. [CrossRef] [PubMed]

34. Medunić, G.; Fiket, Ž.; Ivanić, M. Arsenic contamination status in Europe, Australia, and other parts of the World. In Arsenic in Drinking Water and Food, 1st ed.; Srivastava, S., Ed.; Springer: Singapore, 2020.

35. Nicomel, N.R.; Leus, K.; Folens, K.; Van Der Voort, P.; Du Laing, G. Technologies for arsenic removal from water: Current status and future perspectives. J. Environ. Res. Public Health 2016, 13, 62. [CrossRef]

36. Handley, K.M.; Boothman, C.; Mills, R.A.; Pancost, R.D.; Lloyd, J.R. Functional diversity of bacteria in a ferruginous hydrothermal sediment. ISME J. 2010, 4, 1193-1205. [CrossRef]

37. Casentini, B.; Hug, S.J.; Nikolaidis, N.P. Arsenic accumulation in irrigated agricultural soils in Northern Greece. Sci. Total Environ. 2011, 409, 4802-4810. [CrossRef]

38. Thakur, J.K.; Thakur, R.K.; Ramanathan, A.; Kumar, M.; Singh, S.K. Arsenic contamination of groundwater in Nepal—An overview. Water 2011, 3, 1-20. [CrossRef]

39. Cheng, R.C.; Liang, S.; Wang, H.C.; Beuhler, M.D. Enhanced coagulation for arsenic removal. J. AWWA 1994, 86, 79-90. [CrossRef]

40. Ferguson, J.F.; Gavis, J. A review of the arsenic cycle in natural waters. Water Res. 1972, 6, 1259-1274. [CrossRef]

41. Hering, J.G.; Chiu, V.Q. Arsenic occurrence and speciation in municipal groundwater based supply system. J. Environ. Eng. 2000, 126, 800-807. [CrossRef]

42. Korte, N.E.; Fernando, Q. A review of arsenic (III) in groundwater. Crit. Rev. Environ. Sci. Technol. 1991, 21, 1-39. [CrossRef]

43. Falcó, G.; Llobet, J.M.; Bocio, A.; Domingo, J.L. Daily Intake of Arsenic, Cadmium, Mercury, and Lead by Consumption of Edible Marine Species. J. Agric. Food Chem. 2006, 54, 6106-6112. [CrossRef]

44. Varol, M.; Kaya, G.K.; Sünbül, M.R. Evaluation of health risks from exposure to arsenic and heavy metals through consumption of ten fish species. Environ. Sci. Pollut. Res. 2019, 26, 33311-33320. [CrossRef]

45. Storelli, M.M.; Giacominelli-Stuffler, R.; Storelli, A.; Marcotrigiano, G.O. Accumulation of mercury, cadmium, lead and arsenic in swordfish and bluefin tuna from the Mediterranean Sea: A comparative study. Mar. Pollut. Bull. 2005, 50, 993-1018. [CrossRef]

46. Kampouroglou, E.E.; Economou-Eliopoulos, M. Assessment of the environmental impact by As and heavy metals in lacustrine travertine limestone and soil in Attica, Greece: Mapping of potentially contaminated sites. Catena 2016, 139, 137-166. [CrossRef]

47. Zkeri, E.; Aloupi, M.; Gaganis, P. Natural occurrence of arsenic in groundwater from Lesvos island, Greece. Water Air Soil Pollut 2015, 226, 294. [CrossRef]

48. Price, R.E.; Savon, I.; Planer-Friedrich, B.; Bühring, S.I.; Amend, J.; Pichler, T. Processes influencing extreme As enrichment in shallow-sea hydrothermal fluids of Milos Island, Greece. Chem. Geol. 2013, 348, 15-26. [CrossRef] 
49. Singh, R.; Singh, S.; Parihar, P.; Singh, V.P.; Prasad, S.M. Arsenic contamination, consequences and remediation techniques: A review. Ecotoxicol. Environ. Saf. 2015, 112, 247-270. [CrossRef] [PubMed]

50. Vimercati, L.; Baldassarre, A.; Gatti, M.F.; Gagliardi, T.; Serinelli, M.; De Maria, L.; Caputi, A.; Dirodi, A.A.; Galise, I.; Cuccaro, F.; et al. Non-occupational exposure to heavy metals of the residents of an industrial area and biomonitoring. Environ. Monit. Assess. 2016, 188, 673. [CrossRef] [PubMed]

51. Vimercati, L.; Gatti, M.F.; Gagliardi, T.; Cuccaro, F.; De Maria, L.; Caputi, A.; Quarato, M.; Baldassarre, A. Environmental exposure to arsenic and chromium in an industrial area. Environ. Sci. Pollut. Res. Int. 2017, 24, 11528-11535. [CrossRef] [PubMed]

52. Aguilera, I.; Daponte, A.; Gil, F.; Hernández, A.F.; Godoy, P.; Pla, A.; Ramos, J.L.; DASAHU Group. Urinary levels of arsenic and heavy metals in children and adolescents living in the industrialised area of Ria of Huelva (SW Spain). Environ. Int. 2010, 36, 563-569. [CrossRef]

53. Khlifi, R.; Olmedo, P.; Gil, F.; Feki-Tounsi, M.; Hammami, B.; Rebai, A.; Hamza-Chaffai, A. Biomonitoring of cadmium, chromium, nickel and arsenic in general population living near mining and active industrial areas in Southern Tunisia. Environ. Monit. Assess. 2014, 186, 761-779. [CrossRef]

54. Aloupi, M.; Angelidis, M.O.; Gavriil, A.M.; Koulousaris, M.; Varnavas, S. Influence of geology on arsenic concentrations in ground and surface water in central Lesvos, Greece. Environ. Monit. Assess. 2009, 151, 383-396. [CrossRef]

55. Christodoulidou, M.; Charalambous, C.; Aletrari, M.; Nicolaidou Kanari, P.; Petronda, A.; Ward, N.I. Arsenic concentrations in groundwaters of Cyprus. J. Hydrol. 2012, 468-469, 94-100. [CrossRef]

56. Google Earth. Greece, Eye Alt 1116.55 m, World Imagery. Available online: https://earth.google.com/web (accessed on 26 May 2020).

57. UN (United Nations). Available online: https://www.un.org/sustainabledevelopment/sustainabledevelopment-goals/ (accessed on 7 June 2020).

58. Stamatis, G.; Alexakis, D.; Gamvroula, D.; Migiros, G. Groundwater quality assessment in Oropos-Kalamos basin, Attica, Greece. Environ. Earth Sci. 2011, 64, 973-988. [CrossRef]

59. Varnavas, S.P.; Cronan, D.S. Arsenic, antimony and bismuth in sediments and waters from the Santorini hydrothermal field, Greece. Chem. Geol. 1988, 67, 295-305. [CrossRef]

60. Alexakis, D. Meta-Evaluation of water quality indices. Application into groundwater resources. Water 2020, 12, 1890. [CrossRef]

61. Akter, T.; Jhohura, F.T.; Akter, F.; Chowdhury, T.R.; Mistry, S.K.; Dey, D.; Barua, M.K.; Islam, M.A.; Rahman, M. Water Quality Index for measuring drinking water quality in rural Bangladesh: A cross sectional study. J. Health Popul. Nutr. 2016, 35, 4. [CrossRef] [PubMed]

62. Alexakis, D.; Gamvroula, D. Arsenic, chromium, and other potentially toxic elements in the rocks and sediments of OroposKalamos Basin, Attica, Greece. Appl. Environ. Soil Sci. 2014, 718534. [CrossRef]

63. Tzoraki, O.; Dokou, Z.; Christodoulou, G.; Gaganis, P.; Karatzas, G. Assessing the efficiency of a coastal Managed Aquifer Recharge (MAR) system in Cyprus. Sci. Total. Environ. 2018, 626, 875-886. [CrossRef]

64. Tyrovola, K.; Nikolaidis, N.P.; Veranis, N.; Kallithrakas-Kontos, N.; Koulouridakis, P.E. Arsenic removal from geothermal waters with zero-valent iron-Effect of temperature, phosphate and nitrate. Water Res. 2006, 40, 2375-2386. [CrossRef]

65. Ruiz-Chancho, M.J.; Pichler, T.; Price, R.E. Arsenic occurrence and speciation in Cyclopeneritea, a gastropod inhabiting the arsenic-rich marine shallow-water hydrothermal system off Milos Island, Greece. Chem. Geol. 2013, 348, 56-64. [CrossRef]

66. Angelidis, M.; Grimanis, A.P. Arsenic geochemistry in sediments near the Athens sewage outfall. Mar. Pollut. Bull. 1987, 18, 247-298. [CrossRef]

67. Varnavas, S.P.; Cronan, D.S. Hydrothermal metallogenic processes off the islands of Nisiros and Kos in the Hellenic Volcanic Arc. Mar. Geol. 1991, 99, 109-133. [CrossRef]

68. Varnavas, S.P.; Papavasiliou, C. Submarine hydrothermal mineralization processes and insular mineralization in the Hellenic Volcanic Arc system: A review. Ore Geol. Rev. 2020, 124, 103541. [CrossRef]

69. Varnavas, S.P.; Cronan, D.S. Submarine hydrothermal activity off Santorini and Milos in the Central Hellenic Volcanic Arc: A synthesis. Chem. Geol. 2005, 224, 40-54. [CrossRef]

70. Cronan, D.S.; Varnavas, S.P.; Hodkinson, R. Hydrothermal mineralizing processes and associated sedimentation in the Santorini hydrothermal embayments. Mar. Georesour. Geotechnol. 2000, 18, 77-118. [CrossRef]

71. Hubner, A.; Rahders, E.; Rahner, S.; Halbach, P.; Varnavas, S.P. Geochemistry of hydrothermally influenced sediments of Methana (western Hellenic volcanic arc). Geochemistry 2004, 64, 75-94. [CrossRef]

72. Cronan, D.S.; Varnavas, S.P. Metalliferous sediments off Milos, Hellenic Volcanic Arc. Explor. Min. Geol. 1999, 8, $289-297$.

73. Onishi, H. Arsenic. In Handbook of Geochemistry; Wedepohl, K.H., Ed.; Springer: Berlin, Germany, 1970; Volume 2, pp. 3301-3305.

74. Dando, P.R.; Hughes, J.A.; Thiermann, F. Preliminary observations on biological communities at shallow hydrothermal vents in the Aegean Sea. In Hydrothermal Vents and Processes; Parson, L.M., Walker, C.L., Dixon, D.R., Eds.; Geological Society Special Publication: London, UK, 1995; Volume 87, pp. 303-317.

75. Alexakis, D. Diagnosis of stream sediment quality and assessment of toxic element contamination sources in East Attica, Greece. Environ. Earth Sci. 2011, 63, 1369-1383. [CrossRef]

76. Akun, M.E.; Yamac1, R.F.; Charalambous, C.; Lechtvich, S.; Djamgoz, M.B. The distribution of carcinogenic heavy metals in Cyprus soil. In Survival and Sustainability. Environmental Earth Sciences; Gökçekus, H., Türker, U., LaMoreaux, J., Eds.; Springer: Berlin/Heidelberg, Germany, 2010; pp. 353-359. 
77. Zissimos, A.M.; Cohen, D.R.; Christoforou, I.C. Land use influences on soil geochemistry in Lefkosia (Nicosia) Cyprus. J. Geochem. Explor. 2018, 187, 6-20. [CrossRef]

78. Alexakis, D.; Gamvroula, D.; Theofili, E. Environmental availability of potentially toxic elements in an agricultural Mediterranean site. Environ. Eng. Geosci. 2019, 25, 169-178. [CrossRef]

79. Alexakis, D. Suburban areas in flames: Dispersion of potentially toxic elements from burned vegetation and buildings. Estimation of the associated ecological and human health risk. Environ. Res. 2020, 183, 109153. [CrossRef]

80. Alexakis, D. Contaminated land by wildfire effect on ultramafic soil and associated human health and ecological risk. Land 2020, 9, 409. [CrossRef]

81. Kampouroglou, E.; Economou-Eliopoulos, M. Natural contamination by As and heavy metals in soil, their bio-accumulation and potential sources: The case of a travertine limestone quarry, Greece. Cent. Eur. J. Geosci. 2013, 5, 174-188. [CrossRef]

82. Stylianou, M.; Tsiftes, K.; Gavriel, I.; Kostarelos, K.; Demetriou, C.; Papaioannou, A. Environmental impacts of abandoned sulphide mines-The example of Mathiatis Mine in Cyprus. In Proceedings of the e-Symbiosis International Conference, Athens, Greece, 19-21 June 2014.

83. Lortzie, K.; Stylianou, M.; Kostarelos, K. Assessment of environmental pollution at the abandoned gold-silver enrichment plant in Mitsero, Cyprus. In Proceedings of the 13th International Conference on Environmental Science and Technology, Athens, Greece, 5-7 September 2013.

84. Antivachis, D. The geology of the northern part of the Apliki Cyprus-type ore deposit. Bull. Geol. Soc. Greece 2015, 49, 4-28. [CrossRef]

85. Charalambous, A. A diachronic study of Cypriot copper alloy artefacts. J. Archaeol. Sci. Rep. 2016, 7, 566-573. [CrossRef]

86. Schaeffer, R.; Soeroes, C.; Ipolyi, I.; Fodor, P.; Thomaidis, N.S. Determination of arsenic species in seafood samples from the Aegean Sea by liquid chromatography-(photo-oxidation)-hydride generation-atomic fluorescence spectrometry. Anal. Chim. Acta 2005, 547, 109-118. [CrossRef]

87. Pell, A.; Kokkinis, G.; Malea, P.; Pergantis, S.A.; Rubio, R.; López-Sánchez, J.F. LC-ICP-MS analysis of arsenic compounds in dominant seaweeds from the Thermaikos Gulf (Northern Aegean Sea, Greece). Chemosphere 2013, 93, 2187-2194. [CrossRef] [PubMed]

88. Sazakli, E.; Zouvelou, S.V.; Kalavrouziotis, I.; Leotsinidis, M. Arsenic and antimony removal from drinking water by adsorption on granular ferric oxide. Water Sci. Technol. 2015, 71, 622-629. [CrossRef] [PubMed]

89. Figoli, A.; Fuoco, I.; Apollaro, C.; Chabane, M.; Mancuso, R.; Gabriele, B.; De Rosa, R.; Vespasiano, G.; Barca, D.; Criscuoli, A. Arsenic-contaminated groundwaters remediation by nanofiltration. Sep. Purif. Technol. 2020, 238, 116461. [CrossRef]

90. Figoli, A.; Fuoco, I.; Apollaro, C.; Mancuso, R.; Desiderio, G.; De Rosa, R.; Gabriele, B.; Criscuoli, A. Arsenic removal from natural contaminated groundwaters in Calabria Region (Italy) by Nanofiltration. In Environmental Arsenic in a Changing World (As 2018), Proceedings of the 7th International Congress and Exhibition Arsenic in the Environment, Beijing, China, 1-6 July 2018; Zhu, Y., Guo, H., Bhattacharya, P., Ahmad, A., Bundschuh, J., Naidu, R., Eds.; CRC Press Taylor and Francis Group: London, UK, 2018; pp. 1-5.

91. Azamat, J.; Khataee, A.; Sadikoglu, F. Computational study on the efficiency of $\mathrm{MoS}_{2}$ membrane for removing arsenic from contaminated water. J. Mol. Liq. 2018, 249, 110-116. [CrossRef]

92. Elson, C.M.; Davies, D.H.; Hayes, E.R. Removal of arsenic from contaminated drinking water by a chitosan/chitin mixture. Water Res. 1980, 14, 1307-1311. [CrossRef]

93. Garrido Hoyos, S.E.; Avilés Flores, M.; Ramírez Gonzalez, A.; Grajeda Fajardo, C.; Cardoso Zoloeta, S.; Velásquez Orozco, H. Comparing two operating configurations in a full-scale arsenic removal plant. Case study: Guatemala. Water 2013, 5, 834-851. [CrossRef]

94. McBean, E.A.; Rajib, M.A.; Rahman, M.M. Improved sustainability of water supply options in areas with arsenic-impacted groundwater. Water 2013, 5, 1941-1951. [CrossRef]

95. Ojemaye, M.O.; Okoh, O.O.; Okoh, A.I. Uptake of $\mathrm{Zn}^{2+}$ and $\mathrm{As}^{3+}$ from wastewater by adsorption onto imine functionalized magnetic nanoparticles. Water 2018, 10, 36. [CrossRef]

96. Liang, T.; Li, L.; Zhu, C.; Liu, X.; Li, H.; Su, Q.; Ye, J.; Geng, B.; Tian, Y.; Sardar, M.F.; et al. Adsorption of As(V) by the novel and efficient adsorbent cerium-manganese modified biochar. Water 2020, 12, 2720. [CrossRef]

97. Larroca, F.P.; Olschewski, E.S.; Quino-Favero, J.; Rosales Huamaní, J.; Castillo Sequera, J.-L. Water treatment plant prototype with $\mathrm{pH}$ control modeled on fuzzy logic for removing arsenic using Fe(VI) and Fe(III). Water 2020, 12, 2834. [CrossRef]

98. Xu, X.; Lin, L.; Papelis, C.; Xu, P. Sorption of arsenic from desalination concentrate onto drinking water treatment solids: Operating conditions and kinetics. Water 2018, 10, 96. [CrossRef]

99. Khan, S.U.; Farooqi, I.H.; Usman, M.; Basheer, F. Energy efficient rapid removal of arsenic in an electrocoagulation reactor with hybrid Fe/Al electrodes: Process optimization using CCD and kinetic modeling. Water 2020, 12, 2876. [CrossRef]

100. Bae, J.; Kim, S.; Kim, K.S.; Hwang, H.-K.; Choi, H. Adsorptive removal of arsenic by mesoporous iron oxide in aquatic systems. Water 2020, 12, 3147. [CrossRef]

101. Nam, G.; Kim, M.-S.; Lee, N.; Choi, Y.-H.; Ahn, J.-W. An environmentally benign approach for As (V) absorption from wastewater using untreated coffee grounds-Preliminary results. Water 2017, 9, 867. [CrossRef]

102. Serrano, J.; Leiva, E. Removal of arsenic using acid/metal-tolerant sulfate reducing bacteria: A new approach for bioremediation of high-arsenic acid mine waters. Water 2017, 9, 994. [CrossRef] 
103. Alkhudhiri, A.; Hakami, M.; Zacharof, M.-P.; Homod, H.A.; Alsadun, A. Mercury, arsenic and lead removal by air gap membrane distillation: Experimental study. Water 2020, 12, 1574. [CrossRef]

104. Ogata, F.; Nagai, N.; Toda, M.; Otani, M.; Saenjum, C.; Nakamura, T.; Kawasaki, N. Removal of arsenic (III) ion from aqueous media using complex nickel-aluminum and nickel-aluminum-zirconium hydroxides. Water 2020, 12, 1697. [CrossRef] 